\title{
Smothering of estuarine sandflats by terrigenous clay: the role of wind-wave disturbance and bioturbation in site-dependent macrofaunal recovery
}

\author{
Alf Norkko*, Simon F. Thrush, Judi E. Hewitt, Vonda J. Cummings, Joanna Norkko, \\ Joanne I. Ellis, Greig A. Funnell, Diane Schultz, Iain MacDonald
}

National Institute of Water and Atmospheric Research, PO Box 11-115, Hamilton, New Zealand

\begin{abstract}
Sediment run-off from land has been recognised as a threat to the biodiversity of shallow estuarine and coastal areas. Extreme rainfall events can cause flooding and landslides, which may result in rapid deposition of fine terrigenous sediments and have serious impacts on benthic communities. We designed a field experiment to study the response of intertidal benthos to such depositions of terrigenous clay. The experiment was conducted at 2 contrasting intertidal sites: a sheltered muddy sand habitat and an exposed sand habitat influenced by wind waves. Terrigenous clay ( $50 \%$ water content) was deposited in replicated experimental plots ( $2 \mathrm{~m}$ diameter) at each site in layers $0,3,6$ or $9 \mathrm{~cm}$ thick. The initial response of the resident macrofauna and subsequent recolonisation was monitored over a period of $408 \mathrm{~d}$. Physical and chemical properties of the experimental plots and wave climate at each site were also measured. The experiment demonstrated highly deleterious effects of catastrophic terrigenous clay deposition on estuarine macrobenthic communities. At both sites following clay deposition, the numbers of individuals were reduced by more than $50 \%$ after $3 \mathrm{~d}$ and by more than $90 \%$ after $10 \mathrm{~d}$, irrespective of clay thickness. Mud crabs Helice crassa were the only animals able to emerge through the clay layer. They also exhibited elevated densities in clay treatments over the course of the experiment. After $28 \mathrm{~d}$, a storm occurred (maximum wave height $0.4 \mathrm{~m}$, period $=6 \mathrm{~s}$ ) which dispersed the clay deposits at the exposed sandy site. Recolonisation of the surficial sediments was rapid at the exposed site following this wind-wave disturbance. However, deeper-dwelling animals such as large bivalves had not recovered to levels observed in the control plots by the end of the experiment. At the more sheltered muddy sand site, the clay deposition resulted in long-lasting habitat change; Although the clay was gradually broken up and re-colonised by small crabs and surface dwelling macrofauna, recovery was still incomplete $408 \mathrm{~d}$ after deposition. The results emphasise the role of wind-wave disturbance and transport of sediments and macrofauna with bedload, and the importance of bioturbation by crabs as facilitators of macrobenthic recovery after disturbance.
\end{abstract}

KEY WORDS: Sedimentation · Terrestrial impacts · Estuarine disturbance · Macrofaunal recovery · Bioturbation · Wind waves $\cdot$ New Zealand

\section{INTRODUCTION}

Estuaries are rich in structural and biological diversity and play an important role in the functioning of coastal ecosystems (Heip et al. 1995, Nedwell et al.

*E-mail: a.norkko@niwa.cri.nz
1999). However, changes in land use and modification of coastlines due to human development have both increased rates of sedimentation and changed the areal extent of depositional environments in estuaries (Edgar \& Barrett 2000). In addition, there is growing recognition that terrigenous sediments pose a threat to the biodiversity of estuaries and coastal areas 
(GES AMP 1994, Gray 1997). Episodic events such as landslides, extreme rain events and flooding can result in catastrophic deposition of fine terrigenous sediments and elevated turbidity, with profound influences on the structure and function of macrobenthic communities (Ellis et al. 2000).

Disturbance plays a key role in community regulation (Dayton 1971, Thistle 1981, Pickett \& White 1985) and has become an integrated element in models trying to explain community development (Johnson 1970, Pearson \& Rosenberg 1978, Rhoads et al. 1978, Zajac \& Whitlatch 1985, Thrush \& Whitlatch 2001). Shallow coastal and estuarine macrobenthic communities are subject to a variety of natural physical and biological disturbances that vary in frequency and intensity, as well as in their spatial and temporal extent (Hall et al.
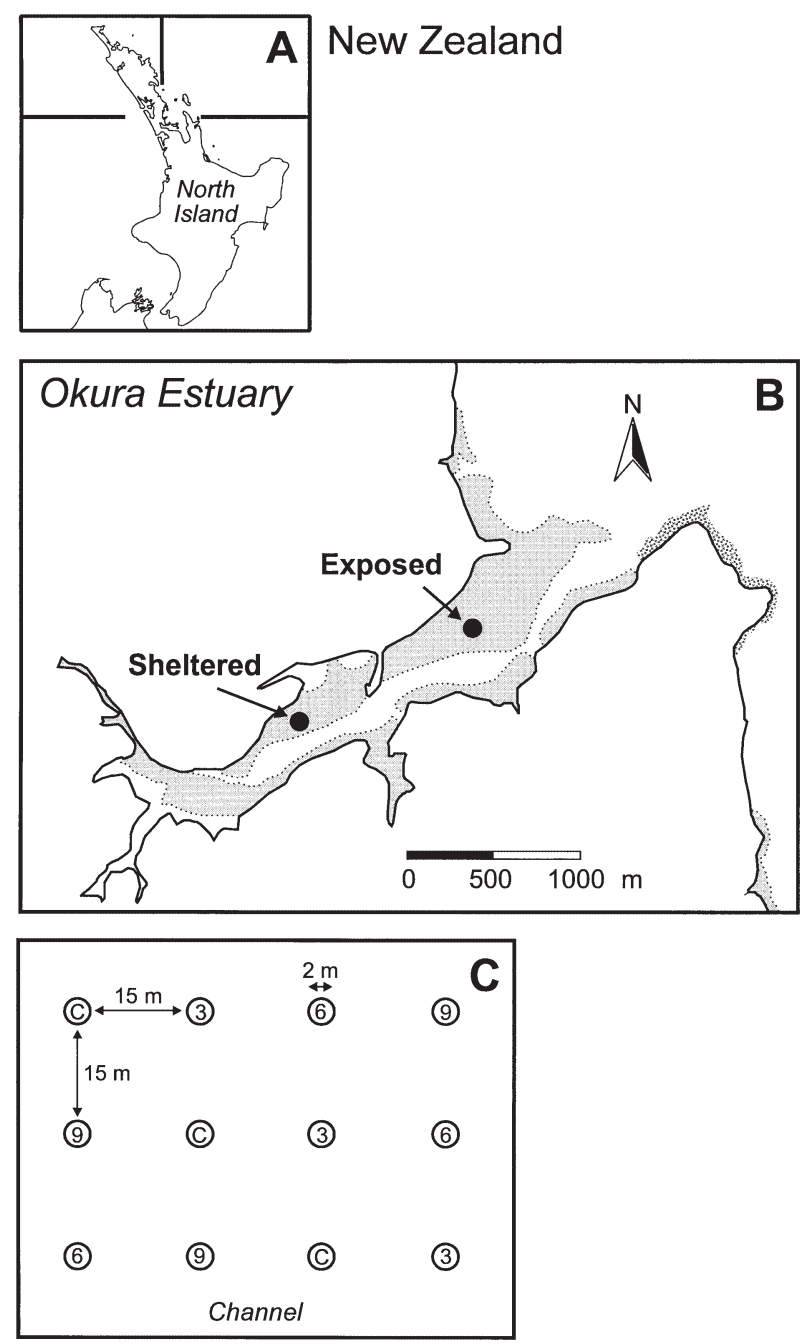

Fig. 1. Location and experimental design. A: position of Okura Estuary in the North Island of New Zealand; B: the study sites; C: arrangement of experimental treatments; $\mathrm{C}=$ control, $3=3 \mathrm{~cm}, 6=6 \mathrm{~cm}, 9=9 \mathrm{~cm}$ clay deposition
1994). In intertidal soft sediment systems, wind waves and tidal currents may disturb macrobenthic communities by initiating sediment transport and removing macrofauna (Yeo \& Risk 1979, Thrush et al. 1996), but at the same time facilitate recovery of localised disturbed patches by transporting benthic diatoms (Miller et al. 1984, Delgado et al. 1991) and different life stages of macrofauna (Butman 1987, Günther 1992). Early colonisation in marine soft sediment systems is scaledependent (Smith \& Brumsickle 1989, Thrush et al. 1996) and a function of the mobility of larvae, juveniles and adults (Santos \& Simon 1980, Whitlatch et al. 1998). Post-settlement transport also serves as an important mechanism for maintaining sandflat communities (e.g. Beukema 1993, Hewitt et al. 1997, Norkko et al. 2001). Colonisation can be both active and passive (Savidge \& Taghon 1988, Emerson \& Grant 1991), but is mediated by hydrodynamic conditions (Commito et al. 1995). Transport processes facilitated by waves and tides operate at a much larger scale than that of experimental plots and are likely to have a site-wide effect on recovery processes. In contrast, biogenic processes such as infaunal bioturbation are likely to vary within experimental plots and thus contribute to differences between treatments and controls. For example, bioturbating infauna can either inhibit succession through e.g. physical disturbance or predation (Rhoads \& Young 1970, Thrush 1988, Warwick et al. 1990, Aarnio et al. 1998), or facilitate succession and recovery by modifying the physical and chemical characteristics of the sediment and hence prime the habitat for colonists after disturbance events (Meadows \& Tait 1989, Wolfrath 1992). Thus, within the context of the spatial scales typically used for experimental plots, bioturbation is expected to play a more pronounced role over smaller scales (Zajac et al. 1998).

Gradients in the intensity of physical and biological processes often occur in estuaries. Thus, both sources of disturbance and the mechanisms important in driving recovery will vary with location. To improve our understanding of benthic recovery processes following disturbance, it is imperative to recognise that different communities and habitats respond differently (e.g. Thrush et al. 1991). Thus, the effects of disturbances will be best understood in the context of the particular environmental conditions that influence the rate of dispersal into the disturbed area and the growth and recovery of the populations (Huston 1994). Catastrophic sedimentation events in estuaries, depositing $\mathrm{cm}$ thick layers of fine terrigenous sediments in short time periods, modify habitats over broad spatial scales and can affect resource availability (Ellis et al. 2000) and lead to mass mortality of benthic fauna (McKnight 1969, Peterson 1985, authors' pers. obs.). Sediment deposi- 
tions affect benthic invertebrates by: (1) physical smothering of the sediment surface causing anoxia; (2) changing sediment grain size affecting porosity/ stability, biogeochemical fluxes, rates of faunal movement and bioturbation; (3) enhancing turbidity, which can clog feeding structures of suspension feeders, and limit light penetration and primary production; and (4) changing sediment food quality.

Naturally occurring catastrophic depositions of fine terrigenous sediments of considerable magnitude have been observed in New Zealand and elsewhere (Peterson 1985, Konar \& Roberts 1996). However, these sedimentation events are unpredictable in time and space, making it difficult to gather information on their ecological effects. We designed a field experiment to test the initial impact and subsequent recovery of intertidal macrobenthic communities exposed to terrigenous sediment layers of different thickness. The experiment was conducted at 2 contrasting intertidal sites within an estuary: a sandy site influenced by wind-wave disturbance and a relatively sheltered muddy sand site. We expected different responses at the 2 sites to the experimental addition of terrigenous clay due to variation in both the initial macrofaunal response (e.g. history of sedimentation events and adaptations to fine sediments) and recovery (variation in rate of colonisation and persistence of terrigenous clay).

\section{MATERIALS AND METHODS}

Study site. The experiment was conducted in Okura Estuary, a 162 ha marine reserve in the North Island of New Zealand (Fig. 1). The estuary is $600 \mathrm{~m}$ wide at the mouth and stretches $3.5 \mathrm{~km}$ inland. Urbanisation of the surrounding 2253 ha catchment has resulted in considerable inputs of sediments to the estuary (A. B. Cooper et al. unpubl.). Two mid-intertidal sites with high macrofaunal diversity, albeit with different community compositions and hydrodynamic conditions, were chosen for the experiment (Fig. 1). The more sheltered site in the inner estuary (hereafter referred to as 'Sheltered'), is dominated by fine to very fine sands (comprising $84.5 \%$ of the volumetric composition; see 'Sediment measurements') and coarse silts (5.9\%), and is less exposed to wind-wave disturbance than the seaward site. The seaward, more exposed site (hereafter 'Exposed') has coarser sediments, dominated by fine to very fine sand $(82.7 \%)$ and coarse sand (9.0\%). Salinity in the estuary is normally around $32 \%$ at both sites, but can in the winter months (June to August) be 20 to $25 \%$. During storm events with heavy flooding from the river salinity can drop as low as $7 \%$ (M. Stewart, pers. comm.). Mud crabs, mainly Helice crassa, occurred in soft sediments throughout the estuary. The benthic community at the Sheltered site was numerically dominated by polychaetes $(42 \%)$, with the spionid Aquilaspio aucklandica being the most common species found, followed by the tellinid bivalve Macomona liliana and the orbinid Scoloplos cylindrifer (Table 1). The Exposed site contained more bivalves (49\%), with the mesodesmatid Paphies australis being the most common species, followed by the nuculid Nucula hartvigiana and the venerid Austrovenus stutchburyi. The spionid Aonides oxycephala and the orbinid Scoloplos cylindrifer were the dominant polychaetes at the Exposed site (Table 1)

Experimental design and the start of the experiment. The aim of the experiment was to mimic a sedimentation event where large quantities of terrigenous fine sediments are deposited in an estuary. Four treatments were used in the experiment: additions of terrigenous silt/clay to produce layers $0,3,6$, and $9 \mathrm{~cm}$ thick to areas of intertidal sandflat. These depths cover the range of natural deposition events observed in Okura and other North Island estuaries (authors' pers. obs.). The experimental treatments were replicated 3 times at each site, with each plot separated by $15 \mathrm{~m}$ (Fig. 1).

On October 31, 1998, clay was obtained from a sediment retention pond created as part of motorway con- 
Table 2. Sampling frequencies and parameters measured at the experimental sites during the course of the experiment. $\mathrm{S}=$ Sheltered site $\mathrm{E}=$ Exposed site. $\mathrm{Chl} a=$ chlorophyll $a$ of the surface sediment; org. content $=$ organic content of the sediment

\begin{tabular}{|c|c|c|c|c|}
\hline $\begin{array}{l}\text { Date } \\
\mathrm{dd} / \mathrm{mm} / \mathrm{yy}\end{array}$ & Day & Macrofauna & $\begin{array}{l}\text { Chl } a_{1} \\
\text { rg. conte }\end{array}$ & $\begin{array}{l}\text { Depth of clay/ } \\
\text { silt-layer }\end{array}$ \\
\hline $\begin{array}{l}30 / 10 / 98 \\
31 / 10 / 98\end{array}$ & -1 & \multicolumn{3}{|c|}{$\begin{array}{c}\text { Baseline samples from S \& E } \\
\text { Start of experiment }\end{array}$} \\
\hline $1 / 11 / 98$ & 1 & & $\mathrm{~S} \& \mathrm{E}$ & $S \& E$ \\
\hline $2 / 11 / 98$ & 2 & & & $S \& E$ \\
\hline $3 / 11 / 98$ & 3 & $S \& E$ & $S \& E$ & $S \& E$ \\
\hline $10 / 11 / 98$ & 10 & $S \& E$ & $\mathrm{~S} \& \mathrm{E}$ & $S \& E$ \\
\hline 2/12/98 & 32 & $S \& E$ & $S \& E$ & $\mathrm{~S}$ \\
\hline 6/1/99 & 67 & $\mathrm{E}$ & $S \& E$ & $\mathrm{~S}$ \\
\hline $31 / 1 / 99$ & 91 & $S \& E$ & $S \& E$ & $\mathrm{~S}$ \\
\hline 2/3/99 & 129 & E & E & S \\
\hline $31 / 3 / 99$ & 151 & $S \& E$ & $S \& E$ & $\mathrm{~S}$ \\
\hline $10 / 6 / 99$ & 222 & $\mathrm{~S}$ & $\mathrm{~S}$ & $\mathrm{~S}$ \\
\hline 25/8/99 & 300 & & $\mathrm{~S}$ & S \\
\hline $13 / 12 / 99$ & 408 & $\mathrm{~S}$ & $\mathrm{~S}$ & $\mathrm{~S}$ \\
\hline
\end{tabular}

struction in the Okura catchment. Fluid sediment was excavated from the pond and mixed into a sedimentfreshwater slurry ( $46 \%$ water content) by an excavator. This sediment closely resembled sediment depositions observed in the Okura estuary after severe storm events. The sediment was deposited into $2 \mathrm{~m}$ diameter circular experimental plots at low tide using a helicopter and monsoon bucket. Each plot had been previously surrounded by a steel band that was pushed into the sediment and protruded from the sediment according to the height of its respective treatment (i.e. 0, 3, 6 and $9 \mathrm{~cm}$ ). After $24 \mathrm{~h}$ the steel surrounds were removed from each plot.

Plots were sampled $1 \mathrm{~d}$ prior to sediment deposition and in a time series following deposition (Table 2). On each sampling occasion, two $10 \mathrm{~cm}$ diameter cores (a total surface area of $157 \mathrm{~cm}^{2}$ ) penetrating $15 \mathrm{~cm}$ into the original sediment were taken from each plot to sample macrofauna. Care was taken to avoid previously sampled areas and the cores were taken at least $30 \mathrm{~cm}$ from the edge of the plots to avoid potential edge effects. After the core samples had been taken, the voids were filled with sieved $(0.5 \mathrm{~mm})$ defaunated sediment and topped with clay to avoid slumping of the surrounding sediments. Over the course of the experiment, only a total of $3.5 \%$ of the plot area was affected by the macrofaunal coring. The cores were sectioned horizontally into the 'top' $(0$ to $2 \mathrm{~cm})$ and 'bottom' (2 to $15 \mathrm{~cm}$ ). This was done in order to identify colonisation of the surface layer. The macrofauna samples were sieved on a $0.5 \mathrm{~mm}$ mesh, preserved in $70 \%$ isopropyl alcohol and stained with $0.2 \%$ Rose Bengal. Macrofauna retained on the sieves were sorted and identified to the lowest level practicable.
Sediment measurements. Five replicate measurements were made of the depth of the terrigenous clay sediment to test for erosion (Table 2). Three core samples ( $2 \mathrm{~cm}$ diameter, $1.5 \mathrm{~cm}$ deep) were obtained from each plot and subsequently analysed for chlorophyll $a$ (chl a), water and organic content, and grain size. Measurements and cores were obtained haphazardly in the vicinity of the macrofaunal cores, at least $30 \mathrm{~cm}$ from the edge of the plot. Chl a was extracted from sediments by boiling in $95 \%$ ethanol, and measured spectrophotometrically. An acidification step was used to separate degradation products from chl a (Sartory 1982). Samples for sediment grain size analysis were digested in $6 \%$ hydrogen peroxide for $48 \mathrm{~h}$ to remove organic matter. A Galai particle analyser (Galai Cis -100, Galai Productions, Migdal Haemek, Israel) was used to measure particle size (\% volume at 1 phi intervals from -1 to 10 phi). Cumulative percent volumes were calculated for the medium sand, fine sand, silt and clay fractions. Organic content of the sediment was measured as loss on ignition in $6 \mathrm{~h}$ at $440^{\circ} \mathrm{C}$, after drying the samples at $60^{\circ} \mathrm{C}$ for $48 \mathrm{~h}$. Photographs, covering an area of $0.25 \mathrm{~m}^{2}$, of each plot were also taken to document sediment characteristics such as crab burrows and other large macrofauna.

Measuring wind waves and disturbance to the sediments. Wind generated waves play a critical role in disturbing the seafloor by initiating sediment transport. At each site a DOBIE wave gauge was deployed to provide time series data on the wave climate (see Thrush et al. 2000, and http://www.niwa.cri.nz/ instrument_systems/dobie.html for a detailed description). DOBIE measured pressure in bursts every 30 min, with each burst consisting of 2048 data points at a sampling interval of $0.2 \mathrm{~s}$. Linear wave theory (see

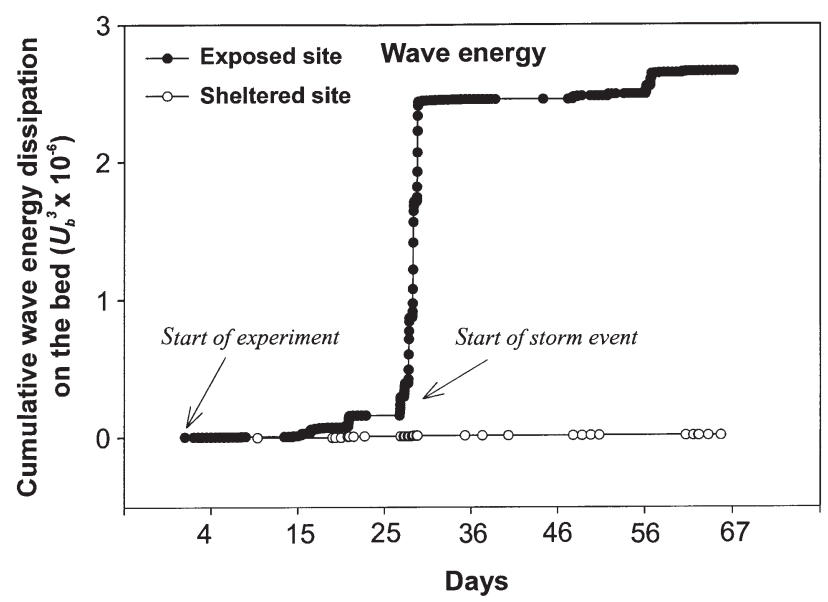

Fig. 2. Cumulative wave energy dissipation on the bed $\left(U_{\mathrm{b}}{ }^{3}\right)$ at the Exposed and Sheltered sites over the first 2 mo of the experiment 
e.g. Kinsman 1984) was used to compute the orbital speed at the bed $\left(U_{\mathrm{b}}, \mathrm{cm} \mathrm{s}^{-1}\right)$ corresponding to the significant wave height, mean spectral period and mean water depth (see e.g. Green \& Black 1999 for details on converting burst pressure data into estimates of $U_{\mathrm{b}}$ ). Since the time-averaged dissipation of wave energy by bed friction is directly proportional to $U_{\mathrm{b}}{ }^{3}$ (Nielsen 1992), we used $U_{\mathrm{b}}{ }^{3}$ to characterise energy dissipation by waves at the site.

To describe the wave energy at the 2 sites needed for initiating sediment transport, the critical wave-orbital speed for initiation of sediment suspension, $U_{\mathrm{w}, \text { crit, }}$ was predicted using Komar \& Miller's (1975) equation:

$$
U_{\mathrm{w}, \text { crit }}^{2}=\left[\left(\rho_{\mathrm{s}}-\rho\right) g D a^{\prime \prime}\left(d_{\mathrm{w}, \text { crit }} / D\right)^{1 / 2}\right] / \rho
$$

where $\rho$ is density of seawater, $D$ is median grain size of the bed sediment, $a^{\prime \prime}$ is an empirical constant (0.21) and $d_{\mathrm{w}, \text { crit }}$ is near-bottom wave-orbital semi-excursion at threshold, which is related to $U_{\mathrm{w}, \text { crit }}$ by $U_{\mathrm{w}, \text { crit }}=$ $2 \pi d_{\mathrm{w}, \text { crit }} / T_{\mathrm{w}}$ where $T_{\mathrm{w}}$ is wave period. $U_{\mathrm{w}, \text { crit }}$ was evaluated using $0.150 \mathrm{~mm}$ for $D$ at both sites and, following Green (1999), the measured mean spectral period, $\bar{T}$, was used for $T_{\mathrm{w}}$. Also following Green (1999), $U_{\mathrm{w}, \text { crit }}$ was compared with measured $U_{\text {sig }}$ to determine whether sediment was in suspension $\left(U_{\text {sig }}>U_{\mathrm{w}, \text { crit }}\right.$ implies suspension).

Statistical analyses. All data are presented as the mean $\pm \mathrm{SD}$. For macrofaunal data, numbers are given per $157 \mathrm{~cm}^{2}$.

Differences between the treatments and the control (for sediment depth, chl a concentrations, organic content, number of individuals, number of taxa, and number of crab burrows) were assessed separately for each site and results are presented in Appendix 1. As no spatial patterns across the sites that could have confounded an ANOVA analysis were observed, variables were analysed by a randomised repeated-measure 1-way ANOVA (Crowder \& Hand 1990, Green 1993), with block as a random factor and treatment as a fixed factor. Data were examined for normality (ShapiroWilk test) and homogeneity of variance (F-max test). No transformations were needed. A sphericity test was used to test that all pairwise covariances among different times were equal. Where this assumption could not be met, the probability levels for $F$ were adjusted by the Huynh-Feldt (1976) method. Where Time $\times$ Treatment interactions were indicated $(p<0.15)$, multiple comparison tests (Scheffe) between each treatment and the control were carried out for each time separately.

Comparisons between Days 10 and 32 (before and after a storm event; Table 2) were made, for sediment chl $a$ and organic content at each site, using paired $t$-tests. Changes in the depth of sand covering the clay over time at the Sheltered site were investigated using
ANCOVA (SAS 1999). Time was represented in $d$ and treated as the independent variable; treatment depth was treated as a fixed categorical factor.

Temporal changes in the structure of macrobenthic communities found in the different treatments were assessed by multidimensional scaling (MDS) ordination on the Bray-Curtis similarity index (Bray \& Curtis 1957) calculated from the raw data for the top and bottom sections of the cores separately (MDS subroutine of the PRIMER software package; Clarke 1993).

\section{RESULTS}

\section{Visual observations}

Over the initial 4 to $5 \mathrm{~d}$ of the experiment, weather conditions were calm and sunny. No immediate reworking of the sediments occurred and the clay layers on all of the experimental plots de-watered, forming a viscous (rubbery) surface. No erosion of clay from the experimental plots was detected. At both sites, crabs were observed crawling up through the clay as it was being deposited and after only a few days, burrows in the clay layer were observed. No other large animals were observed emerging from underneath the clay or colonising the clay, with the exception of the occasional cockle and gastropod found generally in cracks in the clay sediment surface (cracks were caused by shrinkage of the clay as it de-watered). Clay layers at both sites changed very little over the first month of the experiment. A storm event occurred on November 28, $28 \mathrm{~d}$ after the start of the experiment, breaking up and dispersing all of the clay at the Exposed site. Occasional chunks of clay were subsequently found at this site, buried 5 to $10 \mathrm{~cm}$ below the sandy sediment surface, but no terrigenous clay was detected in the control plots. The Sheltered site was largely unaffected by the storm. However, over time the clay at this site became increasingly broken up. The Sheltered site experimental plots slowly sank into the natural muddy sandy sediments, with natural sediments gradually accumulating around and on top of the plots. This effect was strongest in the $3 \mathrm{~cm}$ treatment.

\section{Hydrodynamic conditions and the storm event}

Both experimental sites were immersed by the tide $49 \%$ of the time, but the sites differed substantially in wave climate (Fig. 2). Average and maximum wave heights and periods were significantly higher at the Exposed site. The storm event on Day 28 (Table 3) lasted for approximately $30 \mathrm{~h}$, producing maximum wind speeds of $24 \mathrm{~m} \mathrm{~s}^{-1}$ from the southeast and heavy 
Table 3. Wave climate at the Sheltered and Exposed sites during the storm event $28 \mathrm{~d}$ after the initiation of the experiment. The wave climate for the largest event prior to the storm is also described. $U_{\mathrm{b}}{ }^{3}$ is a measure of energy dissipation on the bed (see text)

\begin{tabular}{|llcc|}
\hline Wave climate & & Sheltered & Exposed \\
\hline Storm event & & & \\
Average wave & height $(\mathrm{m})$ & 0.03 & 0.16 \\
& period (s) & 1.7 & 4.1 \\
& $U_{\mathrm{b}}{ }^{3}\left(\mathrm{~cm}^{3} \mathrm{~s}^{-3}\right)$ & 125 & 19683 \\
Maximum wave & height (m) & 0.1 & 0.4 \\
& period (s) & 2.2 & 6.0 \\
& $U_{\mathrm{b}}{ }^{3}\left(\mathrm{~cm}^{3} \mathrm{~s}^{-3}\right)$ & 2197 & 216000 \\
Largest event prior to storm & & \\
Average wave & height $(\mathrm{m})$ & 0.02 & 0.06 \\
& period $(\mathrm{s})$ & 1.2 & 3.2 \\
& $U_{\mathrm{b}}{ }^{3}\left(\mathrm{~cm}^{3} \mathrm{~s}^{-3}\right)$ & $6.4 \times 10^{-5}$ & $13.3 \times 10^{-4}$ \\
Maximum wave & height $(\mathrm{m})$ & 0.04 & 0.17 \\
& period $(\mathrm{s})$ & 1.5 & 4.5 \\
& $U_{\mathrm{b}}{ }^{3}\left(\mathrm{~cm}^{3} \mathrm{~s}^{-3}\right)$ & 512 & 19683 \\
& & & \\
\hline
\end{tabular}

rain. As an index of wave energy expended on the seabed, maximum $U_{\mathrm{b}}{ }^{3}$ values of $216000 \mathrm{~cm}^{3} \mathrm{~s}^{-3}$ were recorded during the storm at the Exposed site compared to only $2197 \mathrm{~cm}^{3} \mathrm{~s}^{-3}$ at the Sheltered site. This wave energy removed the clay layers from all of the experimental plots at the Exposed site. In contrast, the Sheltered site experimental plots all remained intact. The largest event recorded prior to this storm produced maximum $U_{\mathrm{b}}{ }^{3}$ values of ca. $19683 \mathrm{~cm}^{3} \mathrm{~s}^{-3}$ at the Exposed site (Table 3). This occurred $1 \mathrm{wk}$ before the storm and failed to remove the clay layers.

\section{Sediment characteristics}

The differences in physical regime between the 2 sites are reflected in the ambient sediment characteristics. The Sheltered site had a higher proportion of clay and silt and a lower proportion of medium and coarse sands than the Exposed site (control plots; Table 4).
The experimental clay deposits had very similar sediment characteristics at both sites and were dominated by medium to very fine silts and clays (Table 4). The actual depths of clay deposited at the start of the experiment differed slightly from the ones used for denoting the different treatments. Nevertheless, consistent differences between treatments were apparent. The actual depths measured $12 \mathrm{~h}$ after deposition were around 4, 8 and $10 \mathrm{~cm}$ at both sites. For clarity the treatments are still referred to as 3,6 and $9 \mathrm{~cm}$. At the Sheltered site, where the experimental plots remained intact throughout the experiment, the depth of the terrigenous clay layer decreased over time (Fig. 3a). The $6 \mathrm{~cm}$ treatment clay depth decreased from $8 \mathrm{~cm}$ at the start of the experiment to $5 \mathrm{~cm}$ after $408 \mathrm{~d}\left(\mathrm{r}^{2}=0.662\right.$, $\mathrm{p}<0.0001$ ), while the $9 \mathrm{~cm}$ treatment declined from 10 to $6 \mathrm{~cm}\left(\mathrm{r}^{2}=0.662, \mathrm{p}<0.0001\right)$. The thickness of the $3 \mathrm{~cm}$ treatment clay layer remained more consistent at around $4 \mathrm{~cm}$ over the entire experimental period $\left(\mathrm{r}^{2}=\right.$ $0.0002, \mathrm{p}=0.822$ ). The clay depths were significantly different (i.e. $9>6>3$ ) from each other on all sampling times except for Day 300, when the $9 \mathrm{~cm}$ treatment was different from the $3 \mathrm{~cm}$ treatment, but the $6 \mathrm{~cm}$ was not different from either the 3 or $9 \mathrm{~cm}$ treatments (Fig. 3a, Appendix 1A).

Sediment water content in the control plots at both sites was constant throughout the experiment (22 to $26 \%$ ). The clay treatments $(3,6$ and $9 \mathrm{~cm})$, however, showed a steady de-watering: At the Sheltered site, sediment water content declined from 43 to $48 \%$ on Day 1 to $30 \%$ on Day 99 and to $27 \%$ on Day 408 (Fig. 3c). A similar pattern was observed at the Exposed site, prior to the storm removing the clay layers, after which the re-exposed sand had similar water content to that of the control plots (Fig. 3d). The control plots contained less organic matter than the clay treatment plots at both sites at the beginning of the experiment (i.e. $<1$ vs 4 to $7 \%$; Fig. 3e,f). The organic content of the control treatments was slightly higher at the Sheltered site than at the Exposed site (MannWhitney $U$-test; $\mathrm{p}=0.0082$ ). After the clay was removed by the storm, all plots had similar organic con-

Table 4. Volumetric composition (\%) of the surficial sediments at the start of the experiment. C = control (no sediment added); $3,6,9 \mathrm{~cm}=$ thickness of terrigenous clay deposition

\begin{tabular}{|c|c|c|c|c|c|c|c|c|}
\hline \multirow[t]{2}{*}{ Sediment particle size } & \multicolumn{4}{|c|}{ Sheltered } & \multicolumn{4}{|c|}{ Exposed } \\
\hline & $\mathrm{C}$ & $3 \mathrm{~cm}$ & $6 \mathrm{~cm}$ & $9 \mathrm{~cm}$ & $\mathrm{C}$ & $3 \mathrm{~cm}$ & $6 \mathrm{~cm}$ & $9 \mathrm{~cm}$ \\
\hline Clay (0 to $3.9 \mu \mathrm{m}$ ) & 0.2 & 11.0 & 10.5 & 6.9 & 0.0 & 9.5 & 9.4 & 8.4 \\
\hline Medium to very fine silt (3.9 to $31 \mu \mathrm{m}$ ) & 1.1 & 51.0 & 43.4 & 27.6 & 0.2 & 40.4 & 37.0 & 38.2 \\
\hline Coarse silt (31 to $62.5 \mu \mathrm{m})$ & 5.9 & 24.6 & 21.2 & 22.9 & 0.5 & 15.9 & 18.8 & 28.6 \\
\hline Fine to very fine sand ( 62.5 to $250 \mu \mathrm{m})$ & 84.5 & 11.2 & 12.0 & 30.2 & 82.7 & 16.8 & 17.0 & 21.0 \\
\hline Medium sand (250 to $500 \mu \mathrm{m})$ & 4.4 & 2.2 & 4.7 & 7.8 & 7.6 & 5.5 & 5.6 & 3.8 \\
\hline Coarse sand (500 to $2000 \mu \mathrm{m}$ ) & 3.9 & 0.0 & 8.2 & 4.6 & 9.0 & 11.9 & 12.2 & 0.0 \\
\hline
\end{tabular}


tent values at the Exposed site (Fig. 3f, Appendix 1A). At the Sheltered site, where the clay plots remained intact, the organic content of the clay treatment plots decreased to levels observed in the controls as the experiment progressed (Fig. 3e, Appendix 1A). This reflected the increasing deposition of sediments transported as bedload on top of the plots. The amount of sand accumulating on top of the clay layers increased linearly over time $\left(3 \mathrm{~cm}, \mathrm{r}^{2}=0.91, \mathrm{p}<0.001 ; 6 \mathrm{~cm}, \mathrm{r}^{2}=\right.$
0.96, $\left.\mathrm{p}<0.002 ; 9 \mathrm{~cm}, \mathrm{r}^{2}=0.92, \mathrm{p}<0.007\right)$. The rate was different for each of the treatments, with the largest slope (greatest rate) occurring for the $3 \mathrm{~cm}$ plots (ANCOVA, $\mathrm{p}=0.001$ ). By Day 408, the top $2 \mathrm{~cm}$ of the clay deposits contained 20 to $30 \%$ sand $(>0.125 \mathrm{~mm})$.

Benthic chl $a$ in the control treatments was similar at the Sheltered and Exposed sites (range: 2 to $5.5 \mu \mathrm{g} \mathrm{g}^{-1}$ dry wt; Fig. $3 g, h)$. At the start of the experiment, the
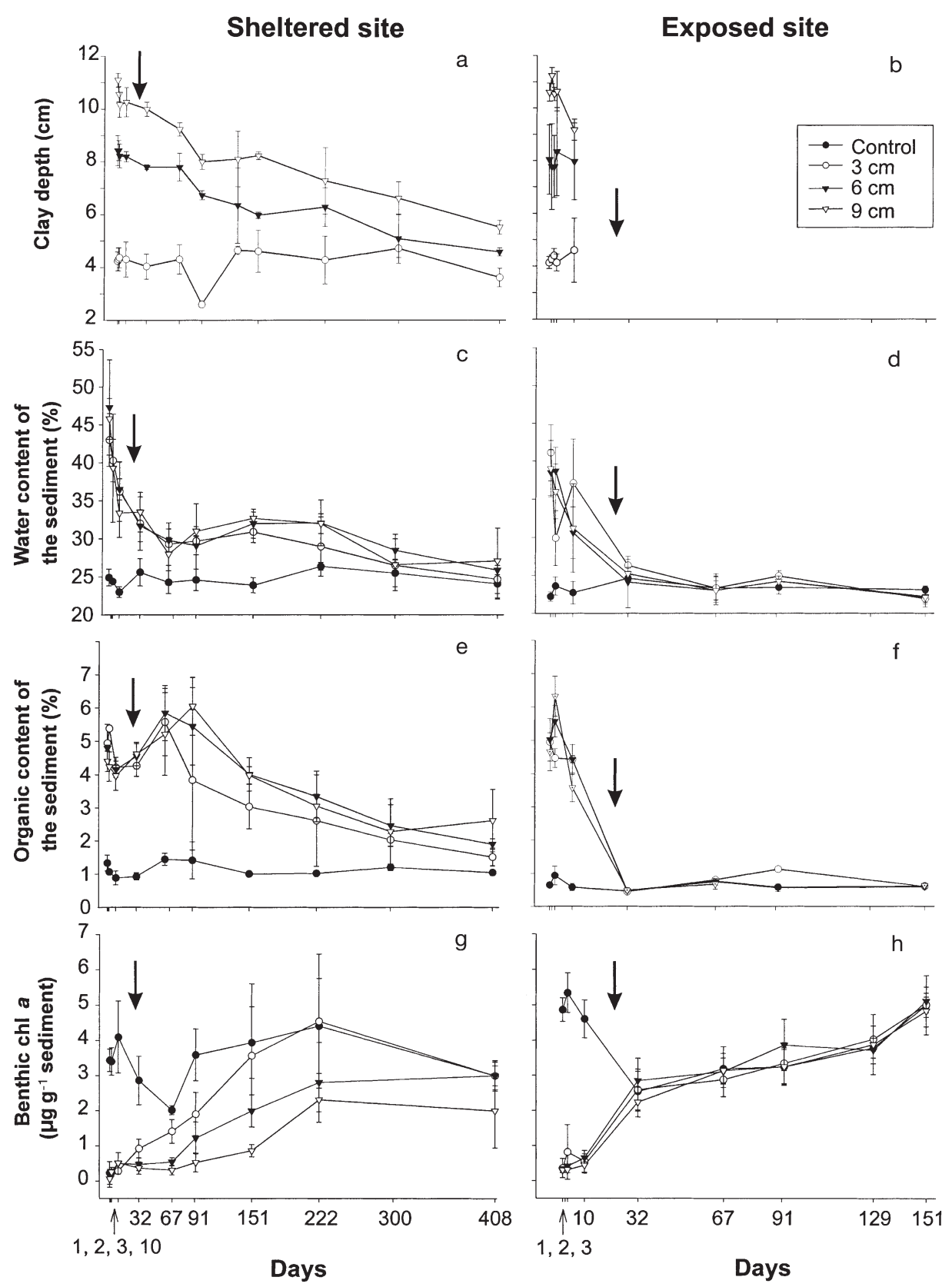

Fig. 3. Sediment characteristics (mean $\pm \mathrm{SD}$ ) at the 2 experimental sites over time. $(\mathrm{a}, \mathrm{b})$ Depth of terrigenous clay deposits; $(c, d)$ water content of sediment; $(e, f)$ organic content of sediment; $(g, h)$ benthic chl $a$. Arrows indicate the storm event on Day 28. Note the difference in scale along the $x$-axis for the 2 sites 


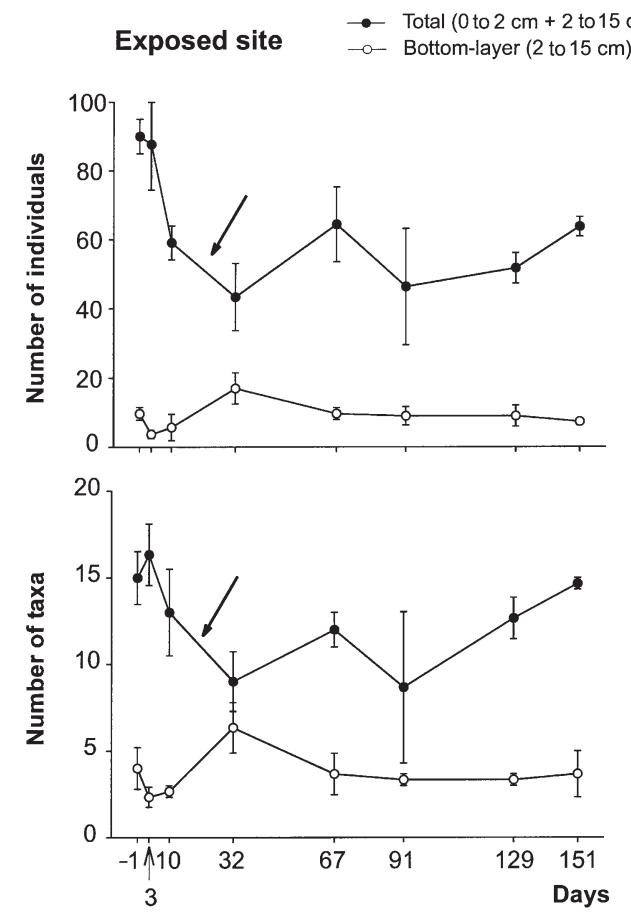

Fig. 4. Number of individuals and taxa (mean \pm SD) per $157 \mathrm{~cm}^{2}$ in the control plots at the Exposed site over the $151 \mathrm{~d}$ study period. Total $=0$ to $2 \mathrm{~cm}+2$ to $15 \mathrm{~cm}$ core sections, Bottom layer $=2$ to $15 \mathrm{~cm}$ section. Day $-1=$ day before clay deposition. The arrows indicate the storm event on Day 28
(Appendix 1A). After 151 d (5 mo), no significant differences could be detected between controls and clay treatments (Appendix 1A). At the Exposed site a significant reduction in chl a occurred in the control plots after the storm (Fig. 3h; $\mathrm{p}=0.0009$, paired $t$-test). The storm removed the terrigenous clay layers from the sandflat, and initial differences in chl a between the control and clay treatments were obliterated. The subsequent recovery was gradual, and at $151 \mathrm{~d}$, chl a concentrations were similar to those detected at the start of the experiment (Fig. 3h).

\section{Disturbance and recovery of macrobenthos \\ Exposed site}

\section{Control plot assemblages}

The number of individuals and taxa found in the control plots varied over the $151 \mathrm{~d}$ period this site was sampled and the highest numbers of individuals and taxa were found in the top $2 \mathrm{~cm}$ of the sediment (Fig. 4). A shift in community composition occurred in conjunction with the storm. The 3 most common species found in the surface sediments $(0$ to $2 \mathrm{~cm}) \mathrm{im}$ mediately prior to the storm (i.e. on Day 10) were the bivalves Paphies australis $(18.3 \pm 5.4 \%)$, Nucula hartvigiana (17.3 $\pm 6.9 \%)$ and Austrovenus stutchburyi clay treatments had significantly less chl a than the control sediments at both sites $(p<0.05 ;$ Appendix 1A). At the Sheltered site, while benthic microalgae colonising the surface of the clay plots were unaffected by the storm, there was an apparent, but non-significant ( $\mathrm{p}=0.149$, paired $t$-test), reduction by about $20 \%$ in benthic chl a in the control plots (Fig. 3g). Colonisation of the clay plots by benthic microalgae was faster in the $3 \mathrm{~cm}$ treatment compared to the 6 and $9 \mathrm{~cm}$ treatments (Fig. 3g). By Day 32, there was significantly more chl $a$ in the $3 \mathrm{~cm}$ treatment than in the 6 and $9 \mathrm{~cm}$ treatments

Fig. 5. Relative difference (mean \pm SD) between control and terrigenous clay treatments for numbers of individuals and taxa in the top $(0$ to $2 \mathrm{~cm}$ ) and deeper (2 to $15 \mathrm{~cm}$ ) sediment layers at the Exposed site over time. Day -1 = day before clay deposition. The arrows indicate the storm event on Day 28
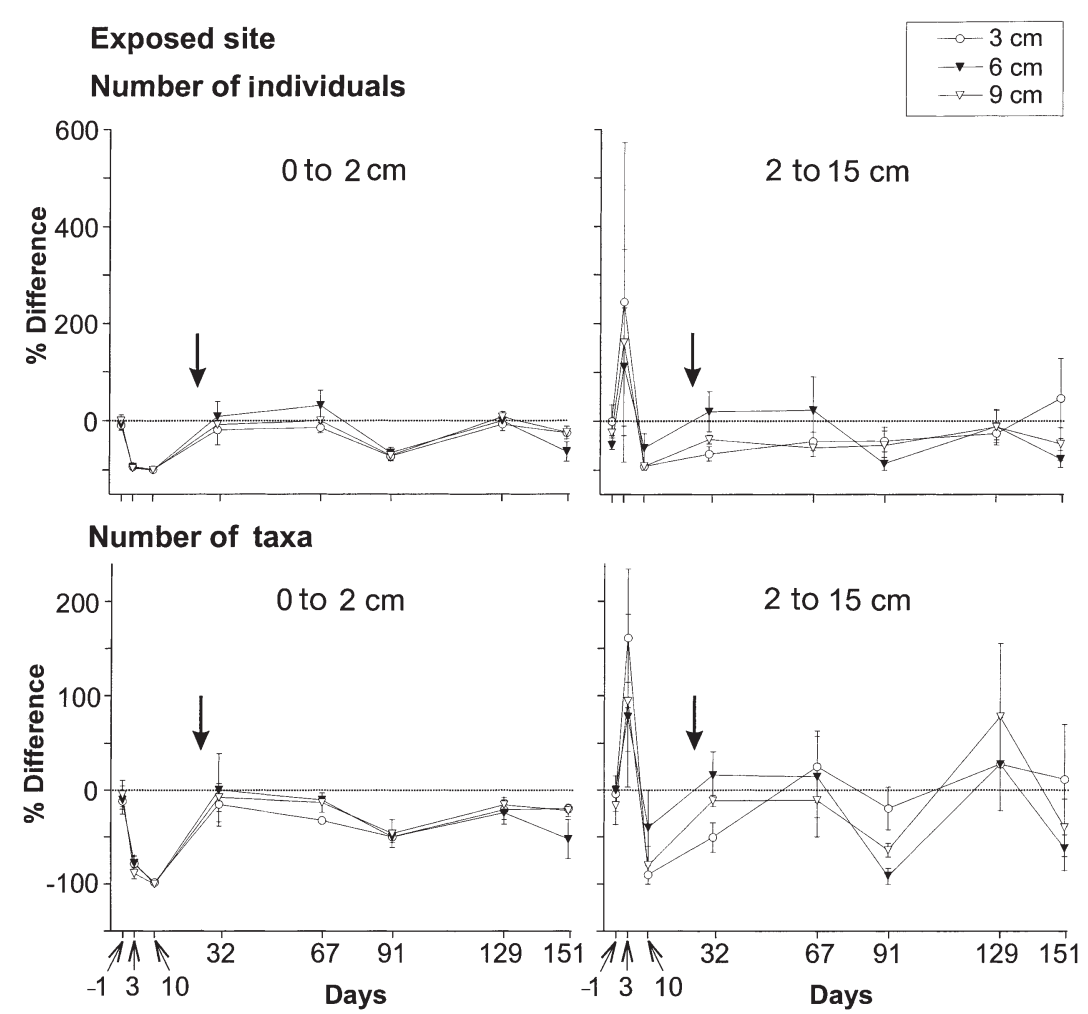
$(12.3 \pm 3.8 \%)$. After the storm (Day 32), Paphies was still the most common species $(19.3 \pm 11.0 \%)$, but the spionid polychaete Aonides oxycephala was the second most common taxon $(15.7 \pm 2.7 \%)$ followed by Nucula $(14.3 \pm 12.8 \%)$. However, this shift in dominance was not persistent but rather relative dominance varied over time amongst the most common species. The dominant taxon in the bottom sediments $(2$ to $15 \mathrm{~cm}$ deep) was large $(>4 \mathrm{~mm}$ ) Macomona liliana. Other numerically important taxa were orbinid, capitellid, nereid and glycerid polychaetes.

\section{Responses of macrofauna to clay deposition}

The macrofaunal community was severely affected by the terrigenous clay within days of the experimental deposition, irrespective of clay depth. After $3 \mathrm{~d}$ the number of individuals and taxa in the clay treatments had declined significantly (Appendix 1B); The number of individuals declined by 57,61 and $69 \%$, and the number of taxa by 57,62 and $83 \%$ in the 3,6 and $9 \mathrm{~cm}$ treatments, respectively. This reduction continued, and after $10 \mathrm{~d}$ the number of taxa had been reduced by $93 \%$ and abundance by $97 \%$ in all clay treatments. There was no obvious migration of macrofauna from the underlying bottom sediments up into the clay layers and, after $10 \mathrm{~d}$, only a few (on average $<1$ ind. $157 \mathrm{~cm}^{-2}$ ) large bivalves (Austrovenus stutchburyi and Paphies australis) were still found alive under the clay. A strong smell of hydrogen sulphide and decaying shellfish was noted from sediments under the clay, even from a few $\mathrm{cm}$ from the edge of the plot.

The number of taxa and individuals in the clay treatments were consistently lower than those found in the control treatment during the first month of the experiment. Fig. 5 shows the mean percent difference in the numbers of taxa and individuals in the clay plots relative to the control plots. A significant reduction in abundance of both taxa and individuals occurred after only $3 \mathrm{~d}$ in the top $2 \mathrm{~cm}$ layer (Fig. 5, Appendix 1B). The wind-wave disturbance associated with the storm event on Day 28 removed all the terrigenous clay layers from the plots. Subsequent recovery of the macrofaunal community was rapid, with few significant differences detected between the clay and control treatments for numbers of taxa or individuals in the bottom sediments for the remainder of the experiment (Fig. 5, Appendix 1B). The top layer also recovered rapidly following the storm event, although numbers of taxa and individuals varied over time (Fig. 5).

Surface-dwelling species such as recent post-settlement stages $(<1 \mathrm{~mm}$ shell length) of the bivalves Nucula hartvigiana, Macomona liliana and Paphies australis, together with paracalliopid amphipods and

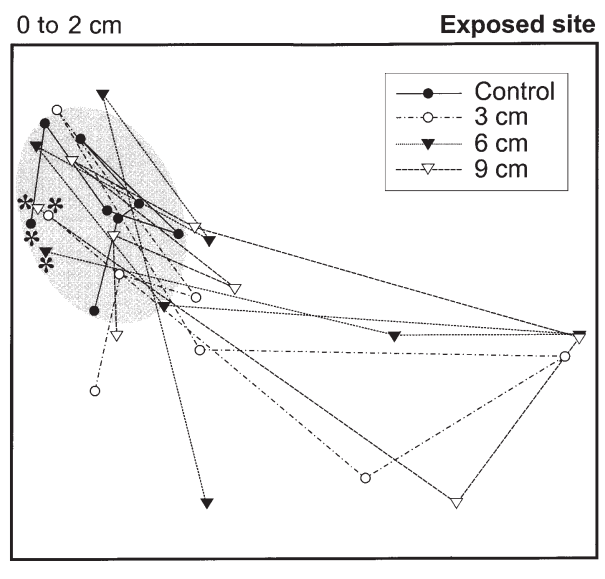

2 to $15 \mathrm{~cm}$

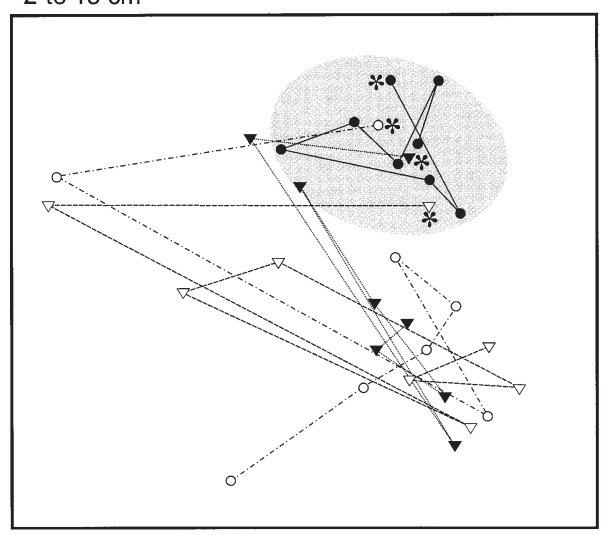

Fig. 6. Multidimensional scaling ordinations (MDS) showing changes in assemblage structure in the different treatments over time at the Exposed site. 0 to $2 \mathrm{~cm}=$ benthic assemblages in surface sediment layer; 2 to $15 \mathrm{~cm}$ = benthic assemblages in deeper sediment layer. *Position of each treatment at the start of the experiment (Day -1). The shaded area encloses the trajectory of the control treatment. Stress value $=0.12$

the polychaetes Scoloplos cylindrifer and Aonides oxycephala, dominated initial recovery. On Day 67, small post-settlement stages of Nucula and Paphies dominated the 3, 6 and $9 \mathrm{~cm}$ treatments, whereas Aquilaspio aucklandica, Paphies and Aonides dominated the control plots. The transient occurrence of these postsettlement bivalves on this exposed sandflat contributed to overall fluctuations in species numbers and abundance over time.

Although recovery occurred in terms of numbers of taxa and individuals, disturbance history appeared to have an effect, with differences in community structure between treatments, apparent on the final sampling (Day 151; Fig. 6). This is clearly shown in the multidimensional scaling analysis (MDS) that portrays the succession in community structure over time for each treatment. At the start of the experiment (Day -1), the communities in all treatments were similar. The 


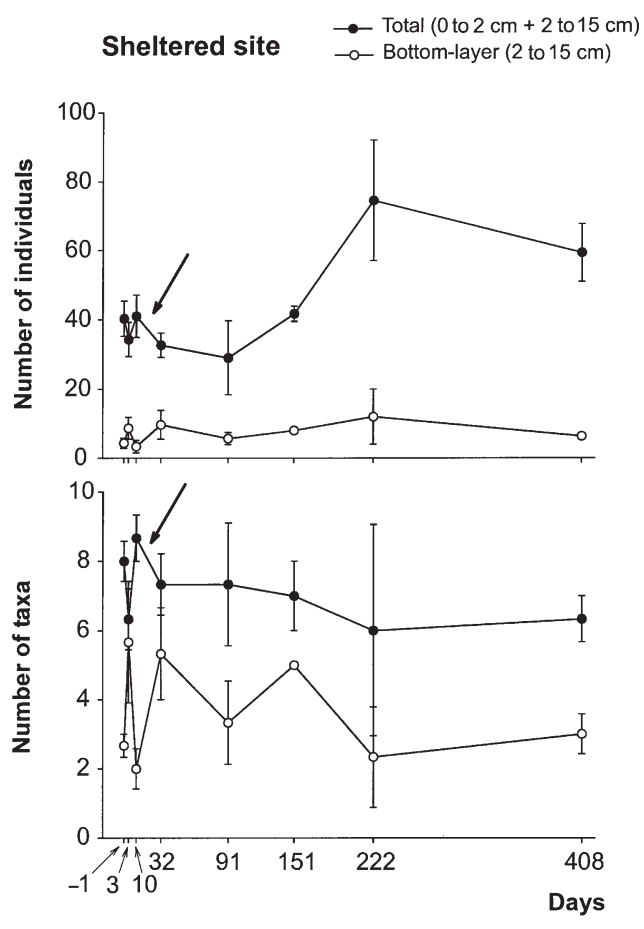

Fig. 7. Number of individuals and taxa (mean \pm SD) per $157 \mathrm{~cm}^{2}$ in the control plots at the Sheltered site over the $408 \mathrm{~d}$ study period. Total $=0$ to $2 \mathrm{~cm}+2$ to $15 \mathrm{~cm}$ core sections, Bottom layer $=2$ to $15 \mathrm{~cm}$ section. Day $-1=$ day before clay deposition. The arrows indicate the storm event on Day 28

control plots exhibited little change over time in both the top or bottom layers of the sediment. A distinct divergence in the ordination space occurred in both layers in all clay treatments after the deposition of clay. Immediately following the storm (Day 32), the community found in the top layer of the clay treatments converged towards a similar location in ordination space as the controls. However, by Day 151, the clay treatment trajectories had diverged again. In comparison, the macrofaunal communities in the bottom layers differed between treatments, and were always distinctly separated in ordination space from the control plot community (Fig. 6).

Fig. 8. Relative difference (mean $\pm \mathrm{SD}$ ) between control and terrigenous clay treatments for numbers of individuals and taxa in the top (0 to $2 \mathrm{~cm})$ and deeper $(2$ to $15 \mathrm{~cm}$ ) sediment layers at the Sheltered site over time. Day $-1=$ day before clay deposition. The arrows indicate the storm event on Day 28
Sheltered site

\section{Control plot assemblages}

The number of taxa in the control plots remained fairly consistent over time (Fig. 7), although lower than those noted for the Exposed site (compare Figs. 4 \& 7). The average total number of taxa found at this site ranged from 6 to 9 per $157 \mathrm{~cm}^{2}$, and similar to the Exposed site, most individuals were found in the top $2 \mathrm{~cm}$ layer of the sediment. Total numbers of individuals increased over the course of the experiment, from around 40 ind. per $157 \mathrm{~cm}^{2}$ early in the experiment to 60 individuals on Day 408. This increase in abundance was largely driven by the recruitment of the polychaetes Aquilaspio aucklandica and Scoloplos cylindrifer to the top $2 \mathrm{~cm}$ layer of the sediment in summer. In contrast, the number of individuals found in the bottom sediments remained consistent over time (5 to 10 ind. per $157 \mathrm{~cm}^{2}$; Fig. 7). A shift in the relative dominance of the 3 most common species, Aquilaspio, Macomona liliana and Scoloplos, was apparent after the storm. For example, the small surface-dwelling Aquilaspio comprised $28.7 \pm 3.3 \%$ of the community on Day 10 , but only $18.7 \pm 5.9 \%$ on Day 32 .

\section{Responses of macrofauna to clay deposition}

The initial community response to clay deposition was similar to that at the Exposed site, i.e. macrofaunal
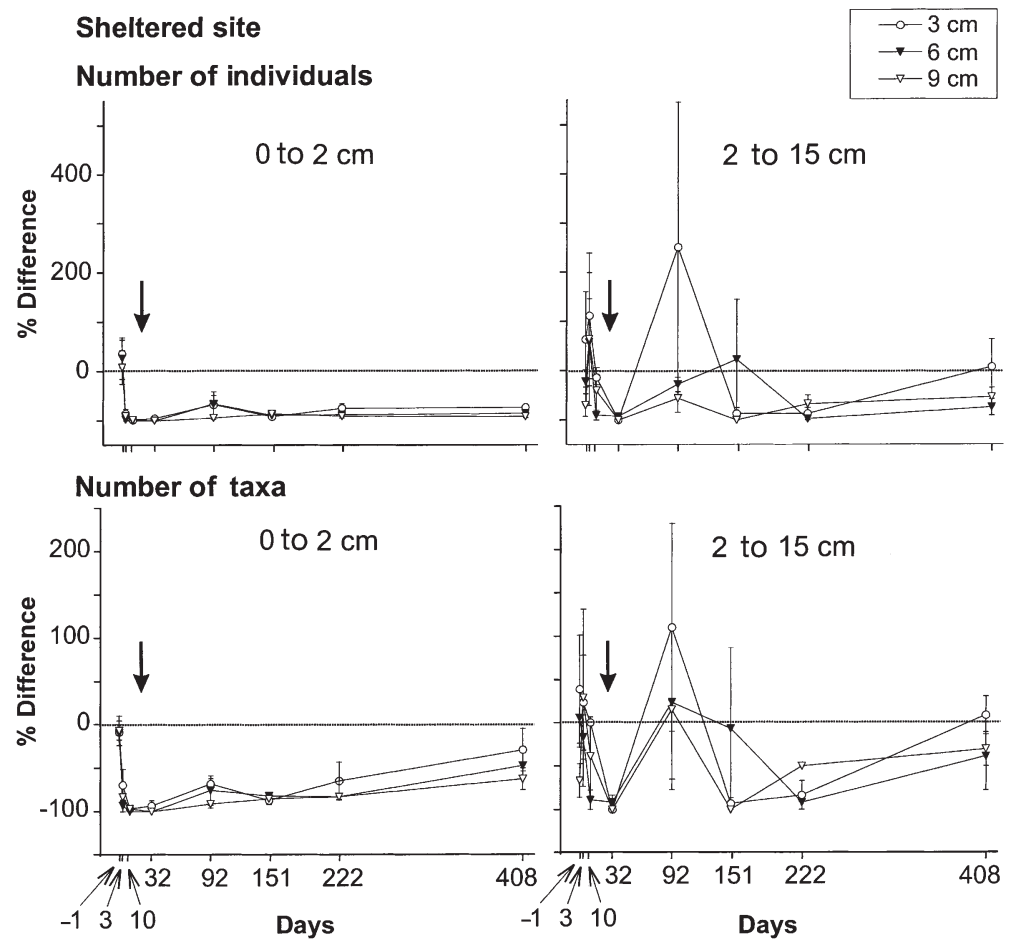
abundance decreased markedly within day, irrespective of depth of the clay layer, and at very similar rates to the Exposed site. No animals except the mud crabs Helice crassa were recorded to have migrated into the clay layers from the underlying sediments. As for the Exposed site, a strong smell of hydrogen sulphide and decaying shellfish was present under the clay. On Day 3, the number of individuals and taxa in the top $2 \mathrm{~cm}$ of the clay treatments had declined significantly (Appendix 1B). The number of individuals had declined by 53,69 and $71 \%$, and the number of taxa by 30,59 and $42 \%$ in the 3,6 and $9 \mathrm{~cm}$ treatments, respectively. After $10 \mathrm{~d}$, the number of taxa in the clay treatments had been reduced by between 82 and $98 \%$ and the number of individuals by between 92 and $98 \%$. Only very few (on average $<1$ ind. per $157 \mathrm{~m}^{2}$ ) Austrovenus stutchburyi, Macomona liliana, and orbinid and capitellid polychaetes were still alive under the clay. After $32 \mathrm{~d}$, the clay treatments contained 0 to $6 \%$ of the taxa, and 0 to $3 \%$ of the individuals found in the control plots. This reduction was significant for both the top and bottom layers of the sediment (Fig. 8, Appendix 1B). After the storm the occasional Austrovenus stutchburyi and gastropods colonised the top of the clay plots. Due to the lower wave energy at this site (Table 3 ), the storm failed to remove the clay layers, and the Sheltered site was thus monitored for a longer time period compared to the Exposed site (i.e. 408 vs $151 \mathrm{~d}$ ).

Recovery was slow and still incomplete after $408 \mathrm{~d}$ (Fig. 8, Appendix 1B). The bottom layer of the sediments contained low numbers of individuals and hence exhibited stochastic fluctuations in the number of species and individuals over time. In the top $2 \mathrm{~cm}$ layer of the sediments, only very slight increases in numbers of individuals could be detected over time and at Day 408 there were still $80 \%$ fewer individuals in the clay treatments compared to the control. No significant differences were detected between clay treatments (Appendix 1B). In terms of taxa, recovery was slightly faster: by Day 408 there were $30 \%$ fewer taxa present in the $3 \mathrm{~cm}$ treatment compared to the control (Fig. 8). Recovery appeared to be treatment dependent, with recovery in the 6 and $9 \mathrm{~cm}$ treatments being slowest (i.e. with $75 \%$ fewer taxa than in the control). Despite these differences, from Day 222 onwards no significant differences in the number of taxa in the top $2 \mathrm{~cm}$ were detected between controls and clay treatments (Appendix 1B).

The pattern of recovery in taxa and their relative abundances is clearly shown in the multidimensional scaling analysis (Fig. 9). Prior to clay deposition (Day -1), the different treatments were closely clustered together in ordination space. A distinct divergence in community composition occurred in all clay treatments after the deposition of clay, both in the top and bottom layers. By Day 408, the community in the top $2 \mathrm{~cm}$ of the clay treatments became slightly more similar to that of the control community, but was still different (Fig. 9). The community in the bottom layers of the clay treatments exhibited a similar pattern, although they were closer in ordination space to the control than the top layers. This is in contrast to the univariate measures which demonstrated partial recovery (Fig. 8, Appendix 1B), hence indicating that changes in community structure were occurring.

Even at this physically less energetic site, bedload transport of sediment appeared to play an important role in transporting colonists to the clay plots. Sand and also adult and post-settlement stages of benthic invertebrates gradually accumulated on top of the clay plots. Similarly to the Exposed site, post-settlement stages of the common bivalves (Nucula hartvigiana, Macomona liliana and Austrovenus stutchburyi) con-
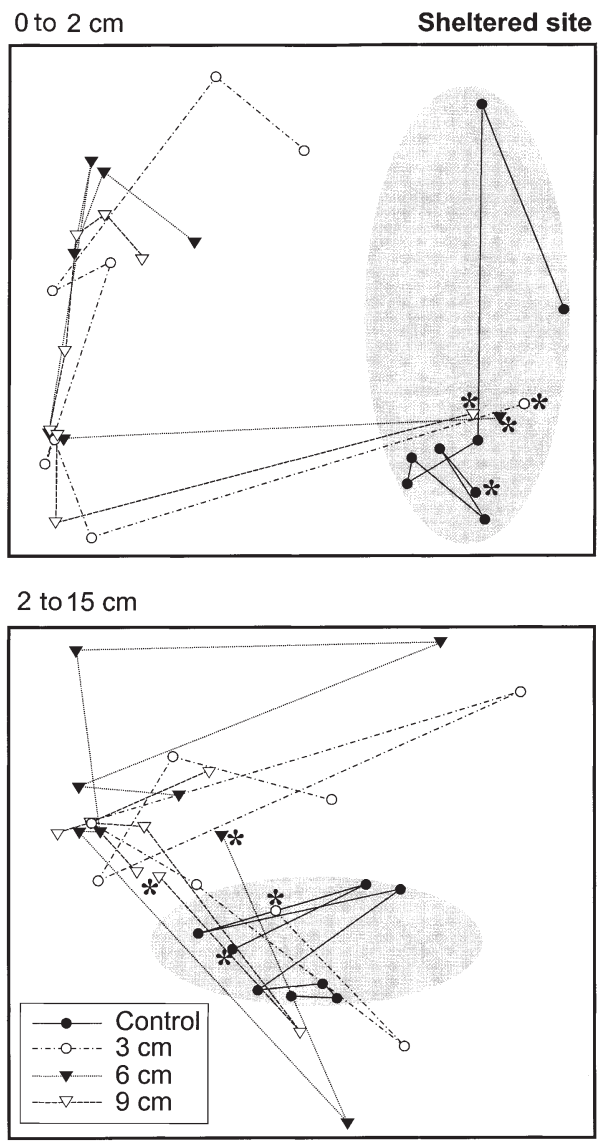

Fig. 9. Multidimensional scaling ordinations (MDS) showing changes in assemblage structure in the different treatments over time at the Sheltered site. 0 to $2 \mathrm{~cm}=$ benthic assemblages in surface sediment layer; 2 to $15 \mathrm{~cm}$ = benthic assemblages in deeper sediment layer. $*$ Position of each treatment at the start of the experiment (Day -1). Shaded area encloses the trajectory of the control treatment. Stress value $=0.12$ 
tributed to recovery, but only in low numbers. Scoloplos cylindrifer was the numerical dominant in the partial recovery process, with a distinct recruitment in the $3 \mathrm{~cm}$ treatment by Day 408 (Fig. 10). A massive seasonal recruitment of Aquilaspio aucklandica was detected in the control plots at Day 408, but virtually none colonised the clay plots (Fig. 10).
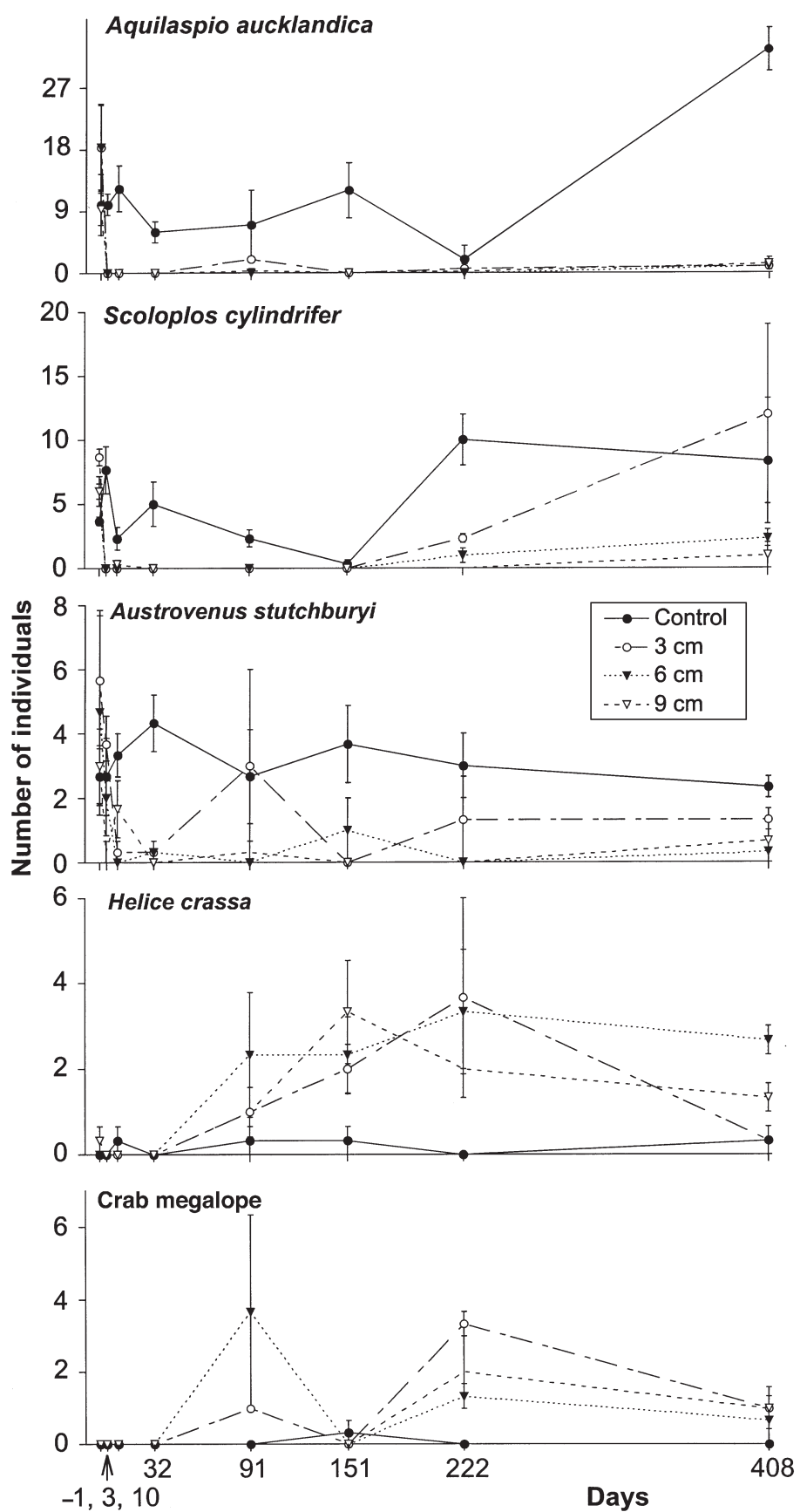

Fig. 10. Abundance (mean $\pm \mathrm{SD}$ ) per $157 \mathrm{~cm}^{2}$ of the common colonising species at the Sheltered site over the $408 \mathrm{~d}$ study period. Day -1 = day before clay deposition
The most dominant feature of the recovery process at the sheltered site was the opportunistic behaviour and colonisation of the clay plots by the mud crab Helice crassa. The clay plots appeared to provide a favourable habitat to the crabs as they quickly colonised the plots (Figs. 10 \& 11). Helice changed the physical characteristics of the clay/silt plots, as was clearly indicated by the rapid increase in abundance of crab burrows (5 to $15 \mathrm{~mm}$ burrow size). Already by Day 10, there were significantly more burrows in the clay treatments than in the control (Appendix 1C). The number of crab burrows increased more quickly in the 6 and $9 \mathrm{~cm}$ treatment compared to the $3 \mathrm{~cm}$ treatment. Two months (Day 67) after clay deposition, between 50 and 100 burrows were counted per $0.25 \mathrm{~m}^{2}$, and an average of over 300 burrows per $0.25 \mathrm{~m}^{2}$ in the $6 \mathrm{~cm}$ treatment at Day 222. Over time, some of these burrows were infilled by sand transported over the clay plots. Thus, burrow numbers decreased again towards the end of the experiment (Fig. 11). The colonisation of the clay plots by Helice occurred as a result of both larval settlement, as indicated by the occurrence of crab megalope in plots (Fig. 10), and through the immigration of juvenile and adult stages. Only very low crab numbers were ever recorded in the control plots (Figs. $10 \& 11$ ).

\section{DISCUSSION}

We designed our experiment to mimic the effects of a catastrophic terrigenous sediment deposition event occurring on the tidal flats of an estuary. Our results clearly demonstrate the direct negative effects of fine and cohesive terrigenous sediments on benthic marine communities. The dominant effect of the sediment deposition was defaunation of the underlying sediments due to physical smothering and the induction of anoxia. Initial responses of benthic macrofauna to the sudden deposition of clay were rapid and virtually identical at the 2 intertidal sites and at the different levels of deposition. After only $3 \mathrm{~d}$, macrofaunal abundance was reduced by up to $69 \%$ at the Exposed site, and by up to $59 \%$ at the Sheltered site, and the sediments underlying the clay depositions were reduced with a distinct odour of hydrogen sulphide. After $10 \mathrm{~d}$, virtually no animals were found alive under the clay. With the exception of mud crabs, no animals were observed to emerge through the clay deposits. After the initial collapse of the benthic communities, the 2 sites followed different recovery pathways, highlighting the importance of site-specific interactions between abiotic and biotic factors influencing succession. The storm removed the clay from the Exposed site and subsequent recovery was rapid. However, the Exposed site continued to exhibit stochastic fluctua- 
tions, perhaps due to the disturbance history, and recovery of large deep burrowing individuals was still not complete after $151 \mathrm{~d}$ (Fig. 6). As the presence of adult deeper-dwelling species, such as Macomona liliana, has been shown to facilitate the colonisation of surface dwelling juveniles (Thrush et al. 1992), it is possible that lack of recovery of the deeper sediments contributed to the apparent instability of the shallow dwelling community. At the Sheltered site, where the clay remained intact, recovery was still incomplete after more than $13 \mathrm{mo}$. Thus, our expectation that there would be differences in the rate and mechanisms of recovery at the 2 sites proved to be correct. However, although the clay deposits persisted at the Sheltered site but not at the Exposed site, no difference in the initial tolerance of resident macrofauna to sedimentation events was detected between the sites.

\section{Initial faunal responses to terrigenous clay deposits}

Recovery following sedimentation events can occur through passive and active migration from surrounding undisturbed areas, through larval colonisation or by the vertical migration of the buried infauna. The capability of benthic invertebrates for vertical migration depends on factors such as the depth of sediment deposition, duration of burial, the composition and temperature of the sediment and the mode of living of the fauna (Maurer et al. 1986). While most benthic invertebrates have an inherent burrowing ability, generally infaunal species such as polychaetes and bivalves are better adapted to movements in sediments than epibenthic species (Stanley 1970, Kranz 1974, Chandrasekara \& Frid 1998). However, the silt content of the sediment can dramatically affect the ability of fauna to emerge through sediments; Maurer et al. (1986) showed that even a $20 \%$ silt-clay content in dredge-disposal sediments dramatically decreased the survival and vertical migration of bivalves and amphipods. These negative effects were further exacerbated in sediments with higher silt-clay content. Kranz (1974) showed responses to be age/size dependent; larger bivalves had higher escape probabilities than smaller ones, but this response differed greatly with species. In our study, with the exception of crabs, which appeared to easily move up through the clay, we saw no evidence of species-dependent differences in the ability of macrofauna to move up through the terrigenous clay layer. Even only $4 \mathrm{~cm}$ of terrigenous sediment proved fatal to benthic invertebrates. Thus, any subtle and fine-scale effects of the deposition of sediments on the macrofaunal community were absent in our study. Laboratory experiments conducted on some of the dominant invertebrate species found in this

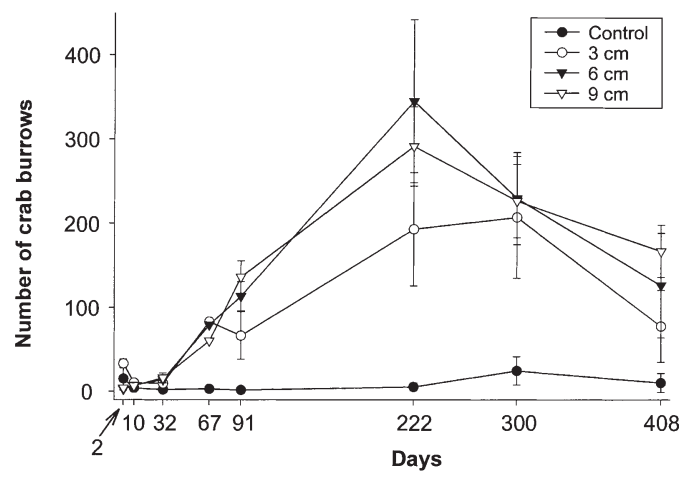

Fig. 11. Number of crab burrows (mean \pm SD) assessed from $0.25 \mathrm{~m}^{2}$ photo quadrates at the Sheltered site over time

study demonstrated that clay sediments of similar composition to that used in this experiment $(50 \%$ water content) failed to provide leverage for animals to move up to the surface (unpubl. data). Initially the clay plots were very fluid but then rapidly de-watered in the sunny and calm weather (Fig. 3). The water content in the clay plots was reduced to around $30 \%$ after $10 \mathrm{~d}$, but by then the benthic community had collapsed.

\section{The role of bioturbation by crabs in modifying the clay deposits}

Crabs played an important role in modifying the terrigenous clay habitat and making it more suitable for other colonising macrofauna, albeit slowly. The small (1 to $2 \mathrm{~cm}$ carapace width) mud crab Helice crassa is an important bioturbator on many New Zealand mudflats and is most abundant in muddy fine sediments, where they can maintain their burrows (Nye 1977, Morrisey et al. 1999). Thus, the deposited clays provided a suitable habitat extension in areas dominated by more sandy sediments. We found high densities of all life stages (i.e. adults, juveniles and megalope) of this crab colonising the clay plots at the Sheltered site. The role of the crabs in remobilising the clay plots was apparent, with a maximum of 350 burrows recorded per $0.25 \mathrm{~m}^{2}$ (Fig. 11). The burrowing activity of mud crabs is likely to promote recovery by mixing the clay with the underlying sediments. Gibbs et al. (2001) have shown this mixing process to be directly linked to the depth of the clay layer and the size of the crabs. In areas dominated by large crabs, the thickness of the clay layer was significantly reduced. Similar to the processes described by Iribarne et al. (1997), burrows were important in trapping natural sediments, thus facilitating recovery.

Crabs are often important habitat modifiers with significant influences on microtopography (Bertness 1985, Thrush 1986) and sediment biogeochemistry 
(Wolfrath 1992), with both direct and indirect effects on the associated macrofauna (Thrush 1988, Botto \& Iribarne 1999). Bioturbation by crabs and other species has been shown to alter recruitment patterns by increasing the mortality of settling larvae (Woodin 1976, Thrush 1988) or increasing survival by providing refuge (Tamaki \& Ingole 1993). The importance of promotive and inhibitive processes can vary with scale, with negative density-dependent effects of bioturbation occurring over small scales while the positive effects of habitat change become more apparent over broader spatial scales (Bertness \& Leonard 1997). Increases in the size and density of biogenic structures such as those created by crabs is often considered a prerequisite and a 'typical' facilitation mechanism for ongoing succession and also a classical end-point in gradients of successional change in soft-sediment communities (Pearson \& Rosenberg 1978, Rhoads et al. 1978, Bonsdorff \& Pearson 1999).

\section{Wind-wave disturbance and sediment transport}

Episodic wind-wave disturbance played a key role in facilitating recovery at the Exposed site. This was demonstrated through the removal of the terrigenous clay layers, the reduction in microphytobenthic biomass (Fig. 3h), and the recovery of the shallow dwelling component of the macrofaunal community (Figs. 5 \& 6). In contrast, the ecological effects of the storm at the Sheltered site were seemingly negligible. Except for extreme cases, storm events are unlikely to remove or kill all organisms; larger and more deepburrowing species are likely to persist (McCall 1977). The potential for waves to influence dispersion and displacement of sediments and benthic invertebrates on estuarine intertidal sandflats is often a function of the interaction between small waves and tidal currents (Bell et al. 1997). The analysis of the wave energy needed for initiating sediment transport $\left(U_{\mathrm{w}, \text { crit }}\right)$ demonstrated that waves initiating transport of the median particle sized sediments found at both sites occurred only $8.5 \%$ of the time at the Sheltered site, but $16 \%$ of the time at the Exposed site. This serves as a relative comparison only, as the role of biogenic processes operating at the sites (e.g. sediment-binding microphytobenthos; Paterson \& Black 1999) are not included in these calculations. Although the Sheltered site was physically benign, sediment transport appeared to influence recovery, as indicated by the increased rate of sand accumulation on top of the clay plots of decreasing thickness. Colonisation by microphytobenthos and benthic invertebrates are likely to be linked to the deposition of sand on the terrigenous clay layers. Microphytobenthos provides an important food source for benthic heterotrophs (e.g. Heip et al. 1995) and hence the concurrent colonisation of microphytobenthos and benthic invertebrates ensures food for the invertebrate colonists. Thus, although lacking the force needed to remove the clay, hydrodynamics still played an important role at the Sheltered site.

\section{Infaunal colonisation}

Intertidal sandflats with high rates of sediment transport are dynamic environments for surface- and near surface-dwelling invertebrates. Dispersal of postsettlement juveniles and adults of benthic invertebrates occurs both passively, associated with sediment bedload transport (e.g. Emerson \& Grant 1991, Commito et al. 1995, Turner et al. 1997), and actively (e.g. Sigurdsson et al. 1976, Beukema \& de Vlas 1989, Armonies 1992, Cummings et al. 1993). Irrespective of whether dispersal is passive or active, the net effects are likely to correlate with the hydrodynamic regime (e.g. Emerson \& Grant 1991). However, significant faunal dispersal can still occur under very low energy wave conditions (Norkko et al. 2001). Macrofaunal species with different modes of living within the sediment will have different potentials to be moved by waves (Tamaki 1987), and thus a combination of behaviour and resistance to transport by waves may result in species-dependent differences in colonisation. At the Sheltered site, juvenile stages of the common bivalves (Nucula hartvigiana, Macomona liliana and Austrovenus stutchburyi) contributed to recovery, but only in low numbers, whereas the orbinid Scoloplos cylindrifer was the numerical dominant in the partial recovery process. The unifying trait for all colonists recorded in our study was mobility, either through the active behaviour of crabs or the recruitment of surface-dwelling species associated with sediment bedload transport. Larval colonisation was also implicated by the presence of occasional crab megalope, and a massive recruitment of the spionid Aquilaspio aucklandica was detected in the control plots at Day 408, but virtually none colonised the clay plots (Fig. 10). It is likely that some of the colonist species actively avoid the terrigenous clay sediments in response to physical or chemical cues (Woodin 1991).

\section{Catchment erosion, catastrophic sediment deposition and habitat change}

Sediment run-off from land has recently been recognised as a significant threat to marine coastal communities (GESAMP 1994), and landscape, land-use, soil types and rainfall are important factors influencing this threat. Problems with land erosion and increasing 
deposition of fine sediment in estuaries are related to the rapid growth of human populations in coastal areas (Gray 1997). A recent Tasmanian study demonstrated a direct relationship between catchment urbanisation (measured as human population density within the catchment) and the increasing silt/clay content of estuaries and changes in the biota (Edgar \& Barrett 2000). Even low human densities $\left(<1\right.$ inhabitant $\left.\mathrm{km}^{-2}\right)$ were found to have resulted in changes in estuarine characteristics. In New Zealand, soil erosion is seen as a major problem (see Griffiths \& Glasby 1985). Apart from catchment urbanisation, soil erosion in $\mathrm{New}$ Zealand is exacerbated by young volcanogenic soils, steep land, deforestation and high annual rainfall. Catchment erosion can occur both through the continuous process of surface erosion, but also through larger slips or landslides that contribute large quantities of sub-surface soils to aquatic systems (Fahey \& Coker 1992, Konar \& Roberts 1996). Our own observations and anecdotal evidence from around New Zealand suggests that such landslide events do occur in connection with storm events, producing massive slugs of fine terrigenous sediments entering estuaries.

\section{Concluding remarks}

Our study suggests that the persistence of terrigenous clay deposits on sandflats depends on location and the prevailing hydrodynamic regime, and the results point at the possibly very destructive effects of heavy sediment deposition events on intertidal softsediment communities. The fine terrigenous clays 'cap' the marine sediments, affecting biogeochemical fluxes and inducing hypoxia and anoxia. These effects were probably intensified because the clay deposits had higher organic content than the surrounding sediments. Despite the relatively small spatial scale of disturbance $\left(3.14 \mathrm{~m}^{2}\right)$ in our experiment, plots remained intact and were persistent in producing long-lasting effects and remarkably slow recovery. Even at the more physically controlled Exposed site, recovery of the deeper sediment layers was incomplete after $151 \mathrm{~d}$. At the Sheltered site, longer-term habitat change resulted. Although the most dramatic effects of disturbance are the short-term consequences of mortality, perhaps the most important effects are the longer-term consequences for resource availability through alteration of habitat (Huston 1994). In such instances 'recovered' post-disturbance communities can become substantially different from pre-disturbance communities. As Edgar \& Barret (2000) pointed out-most temperate estuaries around the world lack pristine reference estuaries that have not already undergone significant changes due to human activities. Thus, we suffer from the problem of reduced expectations and 'shifting baselines' (Dayton et al. 1998) when assessing sedimentation impacts in estuaries. Although sediments have been recognised to pose a threat to coastal biodiversity, very little information is available. More information is urgently needed on the effects of terrigenous sediments on the biota, including the more subtle effects of thinner sediment depositions and the chronic effects of habitat change.

Acknowledgements. We thank Mal Green for help with analysing and interpreting wave data. The help of Robert Van Duivenboden and Chris Hatton (Auckland Regional Council) in organising the helicopter and other logistics is gratefully acknowledged. The comments by the anonymous reviewers helped improve the manuscript. This research was funded by the Auckland Regional Council and the New Zealand Foundation for Research Science and Technology (FRST-C01X0024).

Appendix 1. Results of repeated-measure 1-way ANOVA. Model and error degrees of freedom for individual times $=3$ and 8 . ${ }^{*} p$-value is Huynh-Feldt corrected. Contrasts on individual days are only presented where significant $(p<0.05)$. Lines connect treatments not significantly different from each other. MC: multiple comparisons

\begin{tabular}{|c|c|c|c|c|c|c|c|c|}
\hline Variable & $\mathrm{df}$ & MS & $F$-value & p-value & Day & MS & $\mathrm{p}$-value & $\mathrm{MC}$ \\
\hline \multicolumn{9}{|c|}{ A. Sediment characteristics } \\
\hline \multicolumn{9}{|l|}{ Chl a } \\
\hline \multicolumn{9}{|l|}{ Exposed site } \\
\hline Time & 7 & 18.67 & 142.79 & 0.0001 & 1 & 15.4 & 0.0001 & $C>369$ \\
\hline Time $\times$ Treatment & 21 & 4.207 & 32.16 & 0.0001 & 3 & 17.6 & 0.0001 & $C>\overline{369}$ \\
\hline Error (time) & 56 & 0.130 & & & 10 & 12.3 & 0.0001 & $\mathrm{C}>\underline{639}$ \\
\hline \multicolumn{9}{|l|}{ Sheltered site } \\
\hline Time & 7 & 10.13 & 23.23 & 0.0001 & 1 & 7.53 & 0.0001 & $C>\underline{936}$ \\
\hline Time $\times$ Treatment & 21 & 1.59 & 3.66 & $0.0032^{*}$ & 3 & 10.1 & 0.0001 & $\mathrm{C}>\overline{963}$ \\
\hline \multirow[t]{4}{*}{ Error (time) } & 56 & 0.44 & & & 10 & 4.05 & 0.0002 & $\mathrm{C}>\underline{369}$ \\
\hline & & & & & 32 & 1.87 & 0.0001 & $C>\overline{3>6} 9$ \\
\hline & & & & & 91 & 5.19 & 0.0007 & $C>\underline{369}$ \\
\hline & & & & & 151 & 6.13 & 0.0386 & $C>\overline{369}$ \\
\hline
\end{tabular}


Appendix 1 (continued)

\begin{tabular}{|c|c|c|c|c|c|c|c|c|}
\hline Variable & $\mathrm{df}$ & MS & $F$-value & p-value & Day & MS & $\mathrm{p}$-value & $\mathrm{MC}$ \\
\hline \multicolumn{9}{|c|}{ A. Sediment characteristics (continued) } \\
\hline \multicolumn{9}{|l|}{ Organic content } \\
\hline \multicolumn{9}{|l|}{ Exposed site } \\
\hline Time & 7 & 15.84 & 132.88 & 0.0001 & 1 & 7.613 & 0.0002 & $\underline{963}>\mathrm{C}$ \\
\hline Time $\times$ Treatment & 21 & 2.306 & 19.34 & 0.0001 & 3 & 9.27 & 0.0264 & $\overline{963}>C$ \\
\hline Error (time) & 21 & 0.119 & & & 10 & 5.78 & 0.0038 & $\underline{639}>\mathrm{C}$ \\
\hline \multicolumn{9}{|l|}{ Sheltered site } \\
\hline Time & 8 & 10.97 & 26.23 & 0.0001 & 1 & 8.68 & 0.0001 & $\underline{369}>\mathrm{C}$ \\
\hline Time $\times$ Treatment & 24 & 1.413 & 3.38 & 0.0002 & 3 & 7.71 & 0.0001 & $\overline{369}>\mathrm{C}$ \\
\hline \multirow[t]{5}{*}{ Error (time) } & 64 & 0.418 & & & 10 & 9.54 & 0.0001 & $\overline{963}>C$ \\
\hline & & & & & 32 & 12.8 & 0.0004 & $\overline{639}>\mathrm{C}$ \\
\hline & & & & & 91 & 12.9 & 0.0104 & $\overline{963} \mathrm{C}$ \\
\hline & & & & & 151 & 5.93 & 0.0001 & $69 \overline{3}>C$ \\
\hline & & & & & 222 & 3.23 & 0.0314 & $\underline{693} \mathrm{C}$ \\
\hline \multicolumn{9}{|l|}{ Clay depth } \\
\hline \multicolumn{9}{|l|}{ Exposed site } \\
\hline Time & 3 & 0.471 & 2.47 & 0.0949 & 1 & 36.4 & 0.0004 & $9>6>3$ \\
\hline Time $\times$ Treatment & 6 & 1.07 & 5.62 & 0.0019 & 2 & 28.3 & 0.0001 & $9>6>3$ \\
\hline \multirow[t]{2}{*}{ Error (time) } & 18 & 0.191 & & & 3 & 32.5 & 0.0009 & $\underline{96}>3$ \\
\hline & & & & & 10 & 16.8 & 0.0062 & $\overline{96}>3$ \\
\hline \multicolumn{9}{|l|}{ Sheltered site } \\
\hline Time & 10 & 9.66 & 35.7 & 0.0001 & 1 & 30.5 & 0.0001 & $9>6>3$ \\
\hline Time $\times$ Treatment & 20 & 2.513 & 9.28 & 0.0001 & 2 & 26.1 & 0.0001 & $9>6>3$ \\
\hline \multirow[t]{9}{*}{ Error (time) } & 60 & 0.270 & & & 3 & 27.5 & 0.0001 & $9>6>3$ \\
\hline & & & & & 10 & 27.3 & 0.0001 & $9>6>3$ \\
\hline & & & & & 32 & 19.3 & 0.0001 & $9>6>3$ \\
\hline & & & & & 67 & 23.9 & 0.0001 & $9>6>3$ \\
\hline & & & & & 91 & 9.01 & 0.0177 & $9>6>3$ \\
\hline & & & & & 151 & 10.1 & 0.0002 & $9>6>3$ \\
\hline & & & & & 222 & 7 & 0.0264 & $9>6>3$ \\
\hline & & & & & 300 & 3.04 & 0.03 & $\begin{array}{lll}\underline{9} & \underline{6} & 3 \\
\end{array}$ \\
\hline & & & & & 408 & 2.70 & 0.0004 & $9>\overline{6>3}$ \\
\hline \multicolumn{9}{|l|}{ B. Fauna-full core } \\
\hline \multicolumn{9}{|l|}{ Number of ind. } \\
\hline \multicolumn{9}{|l|}{ Exposed site } \\
\hline Time & 7 & 5121 & 29.5 & 0.0001 & 3 & 2891 & 0.0029 & $C>\underline{369}$ \\
\hline Time $\times$ Treatment & 21 & 588 & 3.34 & 0.001 & 10 & 2456 & 0.0001 & $C>\underline{936}$ \\
\hline Error (time) & 56 & 174 & & & & & & \\
\hline \multicolumn{9}{|l|}{ Sheltered site } \\
\hline Time & 7 & 1260 & 11.61 & 0.0001 & 3 & 210 & 0.0012 & $C>\underline{369}$ \\
\hline Time $\times$ Treatment & 21 & 306 & 2.82 & 0.0014 & 10 & 604 & 0.0001 & $C>\underline{396}$ \\
\hline \multirow[t]{4}{*}{ Error (time) } & 56 & 108 & & & 32 & 690 & 0.0001 & $C>\underline{369}$ \\
\hline & & & & & 151 & 761 & 0.0117 & C $6 \underline{6} 93$ \\
\hline & & & & & 222 & 2310 & 0.0004 & $C>396$ \\
\hline & & & & & 408 & 1463 & 0.0019 & $C>\underline{369}$ \\
\hline \multicolumn{9}{|l|}{ Number of taxa } \\
\hline \multicolumn{9}{|l|}{ Exposed site } \\
\hline Time & 7 & 131 & 28.15 & 0.0001 & 3 & 80.4 & 0.0001 & $C>\underline{369}$ \\
\hline Time $\times$ Treatment & 21 & 18.9 & 4.13 & 0.0001 & 10 & 126 & 0.0001 & $C>\underline{396}$ \\
\hline Error (time) & 56 & 4.56 & & & & & & \\
\hline Sheltered site & & & & & & & & \\
\hline Time & 7 & 77 & 9.58 & 0.00001 & 10 & 106 & 0.0001 & $C>\underline{396}$ \\
\hline Time $\times$ Treatment & 21 & 15.8 & 1.96 & $0.0233^{*}$ & 32 & 80.3 & 0.0001 & $C>369$ \\
\hline Error (time) & 56 & 8.04 & & & 151 & 80.8 & 0.012 & C $\underline{6} 39$ \\
\hline
\end{tabular}


Appendix 1 (continued)

\begin{tabular}{|c|c|c|c|c|c|c|c|c|}
\hline Variable & df & MS & $F$-value & $\mathrm{p}$-value & Day & MS & $\mathrm{p}$-value & $\mathrm{MC}$ \\
\hline \multicolumn{9}{|c|}{ B. Fauna - top $2 \mathrm{~cm}$ of core } \\
\hline \multicolumn{9}{|l|}{ Number of ind. } \\
\hline \multicolumn{9}{|l|}{ Exposed site } \\
\hline Time & 7 & 5048 & 34.75 & 0.0001 & 3 & 4712 & 0.0001 & $\mathrm{C}>\underline{369}$ \\
\hline Time $\times$ Treatment & 21 & 712 & 4.91 & 0.0001 & 10 & 2125 & 0.0001 & $C>\underline{396}$ \\
\hline Error (time) & 56 & 145 & & & & & & \\
\hline \multicolumn{9}{|l|}{ Sheltered site } \\
\hline Time & 7 & 1329 & 26.9 & 0.0001 & 3 & 255 & 0.0003 & $C>\underline{396}$ \\
\hline Time $\times$ Treatment & 21 & 222 & 4.5 & 0.0001 & 10 & 517 & 0.0001 & $C>396$ \\
\hline \multirow[t]{5}{*}{ Error (time) } & 56 & 49.4 & & & 32 & 306 & 0.0001 & $C>\overline{396}$ \\
\hline & & & & & 91 & 382 & 0.0088 & $C>\underline{639}$ \\
\hline & & & & & 151 & 541 & 0.0001 & $C>\overline{963}$ \\
\hline & & & & & 222 & 1651 & 0.0001 & $C>\underline{369}$ \\
\hline & & & & & 408 & 1279 & 0.0017 & $C>\underline{369}$ \\
\hline \multicolumn{9}{|l|}{ Number of taxa } \\
\hline \multicolumn{9}{|l|}{ Exposed site } \\
\hline Time & 7 & 131 & 22.4 & 0.0001 & 3 & 140 & 0.0002 & $C>\underline{369}$ \\
\hline Time $\times$ Treatment & 21 & 25 & 4.25 & 0.0001 & 10 & 125 & 0.0002 & $C>\underline{396}$ \\
\hline Error (time) & 56 & 5.87 & & & & & & \\
\hline \multicolumn{9}{|l|}{ Sheltered site } \\
\hline Time & 7 & 82.4 & 19.8 & 0.0001 & 3 & 24.9 & 0.004 & $C>\underline{396}$ \\
\hline Time $\times$ Treatment & 21 & 7.72 & 1.85 & $0.0810^{*}$ & 10 & 104 & 0.0001 & $C>\overline{396}$ \\
\hline \multirow[t]{3}{*}{ Error (time) } & 56 & 4.16 & & & 32 & 58.1 & 0.0001 & $C>\underline{396}$ \\
\hline & & & & & 91 & 29 & 0.002 & $C>\underline{369}$ \\
\hline & & & & & 151 & 44.3 & 0.0001 & $C>\underline{693}$ \\
\hline \multicolumn{9}{|c|}{ B. Fauna-bottom 2 to $15 \mathrm{~cm}$ of core } \\
\hline \multicolumn{9}{|l|}{ Number of ind. } \\
\hline \multicolumn{9}{|l|}{ Exposed site } \\
\hline Time & 7 & 313 & 12.11 & 0.0001 & 3 & 518 & 0.0402 & $\underline{369}>\mathrm{C}$ \\
\hline Time $\times$ Treatment & 21 & 102 & 3.93 & $0.0004^{*}$ & & & & \\
\hline Error (time) & 56 & 25.9 & & & & & & \\
\hline \multicolumn{9}{|l|}{ Sheltered site } \\
\hline Time & 7 & 42.8 & 0.96 & 0.4699 & 32 & 77.2 & 0.014 & $C>639$ \\
\hline Time $\times$ Treatment & 21 & 43.3 & 0.97 & 0.5115 & & & & \\
\hline Error (time) & 56 & 44.5 & & & & & & \\
\hline \multicolumn{9}{|l|}{ Number of taxa } \\
\hline \multicolumn{9}{|l|}{ Exposed site } \\
\hline Time & 7 & 23 & 10.11 & 0.0001 & 3 & 6.33 & 0.0459 & $369>C$ \\
\hline Time $\times$ Treatment & 21 & 3.82 & 1.67 & 0.0642 & 91 & 6 & 0.0191 & $\overline{\mathrm{C}} 396$ \\
\hline Error (time) & 56 & 2.78 & & & & & & \\
\hline \multicolumn{9}{|l|}{ Sheltered site } \\
\hline Time & 7 & 16.1 & 2.65 & 0.0192 & 32 & 20.5 & 0.0013 & $C>\underline{639}$ \\
\hline Time $\times$ Treatment & 21 & 6.9 & 1.14 & 0.3372 & & & & \\
\hline Error (time) & 56 & 6.05 & & & & & & \\
\hline \multicolumn{9}{|c|}{ C. Crab burrows - sheltered site } \\
\hline Time & 4 & 79153 & 64.1 & 0.0001 & 2 & 590 & 0.0027 & $\underline{3 \quad \mathrm{C}} 96$ \\
\hline Time $\times$ Treatment & 18 & 10518 & 8.52 & 0.0001 & 10 & 20.3 & 0.0108 & $9 \overline{63}>\mathrm{C}$ \\
\hline \multirow[t]{5}{*}{ Error (time) } & 48 & 1235 & & & 32 & 113.6 & 0.0198 & $\underline{693}>C$ \\
\hline & & & & & 151 & 10545 & 0.0001 & $\underline{693}>\mathrm{C}$ \\
\hline & & & & & 222 & 66874 & 0.0008 & $693>C$ \\
\hline & & & & & 300 & 29171 & 0.003 & $\overline{963}>C$ \\
\hline & & & & & 408 & 13565 & 0.0085 & $\overline{963}>C$ \\
\hline
\end{tabular}




\section{LITERATURE CITED}

Aarnio K, Bonsdorff E, Norkko A (1998) Role of Halicryptus spinulosus (Priapulida) in structuring meiofauna and settling macrofauna. Mar Ecol Prog Ser 163:145-153

Armonies W (1992) Migratory rhythms of drifting juvenile molluscs in tidal waters of the Wadden Sea. Mar Ecol Prog Ser 83:197-206

Bell RG, Hume TM, Dolphin TJ, Green MO, Walters RA (1997) Characterisation of physical factors on an intertidal sandflat, Manukau Harbour, New Zealand. J Exp Mar Biol Ecol 216:11-32

Bertness MD (1985) Fiddler crab regulation of Spartina alterniflora production on a New England salt marsh. Ecology 66:1042-1055

Bertness MD, Leonard GH (1997) The role of positive interactions in communities: lessons from intertidal habitats. Ecology 78:1976-1989

Beukema JJ (1993) Successive changes in distribution patterns as an adaptive strategy in the bivalve Macoma balthica (L.) in the Wadden Sea. Helgol Meeresunters 47:287-304

Beukema JJ, de Vlas J (1989) Tidal-current transport of thread-drifting postlarval juveniles of the bivalve Macoma balthica from the Wadden Sea to the North Sea. Mar Ecol Prog Ser 52:293-200

Bonsdorff E, Pearson TH (1999) Variation in the sublittoral macrozoobenthos of the Baltic Sea along environmental gradients: a functional group approach. Aust J Ecol 24:312-326

Botto F, Iribarne O (1999) Effect of the burrowing crab Chasmagnathus granulata (Dana) on the benthic community of a SW Atlantic coastal lagoon. J Exp Mar Biol Ecol 241:263-284

Bray JR, Curtis JT (1957) An ordination of the upland forest communities of southern Wisconsin. Ecol Monogr 27: 325-349

Butman CA (1987) Larval settlement and soft-sediment invertebrates: the spatial scales of pattern explained by active habitat selection and the emerging role of hydrodynamical processes. Oceanogr Mar Biol Annu Rev 25:113-165

Chandrasekara WU, Frid CLJ (1998) A laboratory assessment of the survival and vertical movement of two epibenthic gastropod species, Hydrobia ulvae (Pennant) and Littorina littorea (Linnaeus), after burial in sediment. J Exp Mar Biol Ecol 221:191-207

Clarke KR (1993) Non-parametric multivariate analyses of changes in community structure. Aust J Ecol 18:117-143

Commito JA, Thrush SF, Pridmore RD, Hewitt JE, Cummings VJ (1995) Dispersal dynamics in a wind-driven benthic system. Limnol Oceanogr 40:1513-1518

Crowder MJ, Hand DJ (1990) Analysis of repeated measures. Chapman \& Hall, New York

Cummings VJ, Pridmore RD, Thrush SF, Hewitt JE (1993) Emergence and floating behaviours of post-settlement juveniles of Macomona liliana (Bivalvia: Tellinacea). Mar Behav Physiol 24:25-32

Dayton PK (1971) Competition, disturbance and community organisation: the provision and subsequent utilization of space in a rocky intertidal community. Ecol Monogr 41: 351-389

Dayton PK, Tegner MJ, Edwards PB, Riser KL (1998) Sliding baselines, ghosts, and reduced expectations in kelp forest communities. Ecol Appl 8:309-322

Delgado M, de Jonge VN, Peletier H (1991) Experiments on resuspension of natural microphytobenthos populations. Mar Biol 108:321-328

Edgar GJ, Barrett NS (2000) Effects of catchment activities on macrofaunal assemblages in Tasmanian estuaries. Estuar Coast Shelf Sci 50:639-654
Ellis JI, Norkko A, Thrush SF (2000) Broad-scale disturbance of intertidal and shallow sublittoral soft-sediment habitats; effects on the benthic macrofauna. J Aquat Ecosyst Stress Recovery 7:57-74

Emerson CW, Grant J (1991) The control of soft-shell clam (Mya areanaria) recruitment on intertidal sandflats by bedload sediment transport. Limnol Oceanogr 36:1288-1300

Fahey BD, Coker RJ (1992) Sediment production from forest roads in Queen Charlotte Forest and potential impact on marine water quality, Marlborough Sounds, New Zealand. NZ J Mar Freshw Res 26:187-195

GESAMP (Group of Experts on the Scientific Aspects of Marine environmental Protection) (1994) Anthropogenic influences on sediment discharge to the coastal zone and environmental consequences. Rep Stud GESAMP 52. UNESCO-TOC, Paris

Gibbs M, Thrush SF, Ellis JI (2001) Terrigenous clay deposition on estuarine sandflats: using stable isotopes to determine the role of the mud crab, Helice crassa Dana, in the recovery process. Isot Environ Health Stud 37:113-131

Gray JS (1997) Marine biodiversity: patterns, threats and conservation needs. Biodivers Conserv 6:153-175

Green MO (1999) Test of sediment initial-motion theories using irregular-wave field data. Sedimentology 46:427-441

Green MO, Black KP (1999) Suspended-sediment reference concentration under waves: field observations and critical analysis of two predictive models. Coastal Eng 38:115-141

Green RH (1993) Application of repeated measures designs in environmental impact and monitoring studies. Aust J Ecol 18:81-98

Griffiths GA, Glasby GP (1985) Input of river-derived sediment to the continental shelf. Estuar Coast Shelf Sci 21:773-787

Günther CP (1992) Dispersal of intertidal invertebrates: a strategy to react to disturbances of different scales? Neth J Sea Res 30:45-56

Hall SJ, Raffaelli DG, Thrush SF (1994) Patchiness and disturbance in shallow water assemblages. In: Giller PS, Hildrew AG, Raffaelli DG (eds) Aquatic ecology: scale, pattern and process. Blackwell Scientific Publications, London, p 333-375

Heip, CHR, Goosen NK, Herman PMJ, Kromkamp J, Middelburg JJ, Soetaert K (1995) Production and consumption of biological particles in temperate tidal estuaries. Oceanogr Mar Biol Annu Rev 33:1-149

Hewitt JE, Pridmore RD, Thrush SF, Cummings VJ (1997) Assessing the short-term stability of spatial patterns of macrobenthos in a dynamic estuarine system. Limnol Oceanogr 42:282-288

Huston MA (1994) Biological diversity: the coexistence of species on changing landscapes. Cambridge University Press, Cambridge

Huynh H, Feldt LS (1976) Estimation of the box correction for degrees of freedom from sample data in the randomised block and split plot designs. J Educ Stat 1:69-82

Iribarne O, Bortulus A, Botto F (1997) Between-habitat differences in burrow characteristics and trophic modes in the southwestern Atlantic burrowing crab Chasmagnathus granulata. Mar Ecol Prog Ser 155:132-145

Johnson RG (1970) Variation in diversity within benthic marine communities. Ecology 71:2044-2052

Kinsman B (1984) Wind waves: their generation and propagation on the ocean surface. Dover Publications, New York

Komar PD, Miller MC (1975) On the comparison between the threshold of sediment motion under waves and unidirectional currents with a discussion of the practical evaluation of the threshold. J Sediment Petrol 45:362-367

Konar B, Roberts C (1996) Large scale landslide effects on two 
exposed rocky subtidal areas in California. Mar Biol 39: 517-524

Kranz PM (1974) The anastrophic burial of bivalves and its paleological significance. J Geol 82:237-265

Maurer D, Keck RT, Tinsman JC, Leathem WA, Wethe C, Lord C, Church TM (1986) Vertical migration and mortality of marine benthos in dredged material: a synthesis. Int Rev Gesamten Hydrobiol 71:49-63

McCall PL (1977) Community patterns and adaptive strategies of the infaunal benthos of Long Island Sound. J Mar Res 35:221-266

McKnight DG (1969) A recent, possibly catastrophic burial in a marine molluscan community. NZ J Mar Freshw Res 3: $177-179$

Meadows PS, Tait J (1989) Modifications of sediment permeability and shear strength by two burrowing invertebrates. Mar Biol 101:75-82

Miller DC, Jumars PA, Nowell ARM (1984) Effects of sediment transport on deposit feeding: scaling arguments. Limnol Oceanogr 29:1202-1217

Morrisey D, De Witt TH, Roper DS, Williamson RB (1999) Variation in the depth and morphology of burrows of the mud crab Helice crassa among different types of intertidal sediment in New Zealand. Mar Ecol Prog Ser 182:231-242

Nedwell DB, Raffaelli DG, Fritter AH (1999) Estuaries: advances in ecological research, Vol. 29. Academic Press, London

Nielsen P (1992) Coastal bottom boundary layers and sediment transport. World Scientific, Singapore

Norkko A, Cummings VJ, Thrush SF, Hewitt JE, Hume T (2001) Local dispersal of juvenile bivalves: implications for sandflat ecology. Mar Ecol Prog Ser 212:131-144

Nye PA (1977) Reproduction, growth and distribution of the grapsid crab Helice crassa (Dana 1851) in the southern part of New Zealand. Crustaceana 33:75-89

Paterson DM, Black KS (1999) Water flow, sediment dynamics and benthic ecology. Adv Ecol Res 29:155-193

Pearson TH, Rosenberg R (1978) Macrobenthic succession in relation to organic enrichment and pollution of the marine environment. Oceanogr Mar Biol Annu Rev 16:229-311

Peterson CH (1985) Patterns of lagoonal bivalve mortality after heavy sedimentation and their paleocological significance. Paeleobiology 11:139-153

Pickett STA, White PS (1985) The ecology of patch disturbance and patch dynamics. Academic Press, Orlando

Rhoads DC, Young DK (1970) The influence of depositfeeding organisms on sediment stability and community trophic structure. J Mar Res 28:150-178

Rhoads DC, McCall PL, Yingst JY (1978) Disturbance and production on the estuarine seafloor. Am Sci 66:577-586

Santos SL, Simon JL (1980) Marine soft-bottom community establishment following annual defaunation: larval or adult recruitment. Mar Ecol Prog Ser 2:235-241

Sartory DP (1982) Spectrophotometric analysis of chlorophyll $a$ in freshwater phytoplankton. Tech Rep 115, Hydrological Research Institute, Pretoria

Savidge WB, Taghon GT (1988) Passive and active components of colonisation following two types of disturbance on intertidal sandflat. J Exp Mar Biol Ecol 115:137-155

Sigurdsson JB, Titman CW, Davies PA (1976) The dispersal of young post-larval bivalve molluscs by byssus threads. Nature 262:386-387

Smith CR, Brumsickle SJ (1989) The effect of patch size and substrate isolation on colonization modes and rates in an intertidal sediment. Limnol Oceanogr 34:1263-1277

Stanley SM (1970) Relation of shellform to life habits in the Bivalvia (Mollusca). Geol Soc Am Mem 125:1-296
Tamaki A (1987) Comparison of resistivity to transport by wave action in several polychaete species on an intertidal sand flat. Mar Ecol Prog Ser 37:181-189

Tamaki A, Ingole B (1993) Distribution of juvenile and adult ghost shrimps, Callianassa japonica Ortmann (Thalassinidea), on an intertidal sand flat: intraspecific facilitation as a possible pattern-generating factor. J Crustac Biol 13: 175-183

Thistle D (1981) Natural physical disturbances and the communities of marine soft bottoms. Mar Ecol Prog Ser 6: $223-228$

Thrush SF (1986) Spatial heterogeneity in subtidal gravel generated by the pit-digging activity of Cancer pagurus. Mar Ecol Prog Ser 30:221-227

Thrush SF (1988) The comparison of macrobenthic recolonization patterns near and away from crab burrows on a sublittoral sand flat. J Mar Res 46:669-681

Thrush SF, Whitlatch RB (2001) Recovery dynamics in benthic communities: balancing detail with simplification. In: Reise $\mathrm{K}$ (ed) Ecological comparisons of sedimentary shores. Ecological studies, Vol. 151. Springer Verlag, Berlin, p 298-316

Thrush SF, Pridmore RD, Hewitt JE, Cummings VJ (1991) Impact of ray feeding disturbances on sandflat macrobenthos: do communities dominated by polychaetes or shellfish respond differently? Mar Ecol Prog Ser 69:245-252

Thrush SF, Pridmore RD, Hewitt JE, Cummings VJ (1992) Adult infauna as facilitators of colonization on intertidal sandflats. J Exp Mar Biol Ecol 159:253-265

Thrush SF, Whitlatch RB, Pridmore RD, Hewitt JE, Cummings VJ, Maskery M (1996) Scale-dependent recolonization: the role of sediment stability in a dynamic sandflat habitat. Ecology 77:2472-2487

Thrush SF, Hewitt JE, Cummings VJ, Green MO, Funnell GA Wilkinson MR (2000) The generality of field experiments: interactions between local and broad-scale processes. Ecology 81:399-415

Turner SJ, Grant J, Pridmore RD, Hewitt JE, Wilkinson MR, Hume TM, Morissey DJ (1997) Bedload and water-column transport and colonization processes by post-settlement benthic macrofauna: does infaunal density matter? J Exp Mar Biol Ecol 216:51-75

Warwick RM, Clarke KR, Gee JM (1990) The effect of disturbance by soldier crabs Mictyris platycheles H. Milne Edwards on meiobenthic community structure. J Exp Mar Biol Ecol 135:19-33

Whitlatch RB, Lohrer AM, Thrush SF, Pridmore RD, Hewitt JE, Cummings VJ, Zajac RN (1998) Scale-dependent benthic recolonization dynamics: life stage-based dispersal and demographic consequences. Hydrobiology 375/376:217-226

Wolfrath B (1992) Burrowing of the fiddler crab Uca tangeri in the Rio Formosa in Portugal and its influence on sediment structure. Mar Ecol Prog Ser 85:237-243

Woodin SA (1976) Adult-larval interactions in dense faunal assemblages: patterns of abundance. J Mar Res 34:25-41

Woodin SA (1991) Recruitment of infauna: positive or negative cues? Am Zool 31:797-807

Yeo RK, Risk MJ (1979) Intertidal catastrophes: effect of storms and hurricanes on intertidal benthos of the Minas Basin, Bay of Fundy. J Fish Res Board Can 36:667-669

Zajac RN, Whitlatch RB (1985) A hierarchical approach to modelling soft-bottom successional dynamics. In: Gibbs P (ed) Proc 19th Eur Mar Biol Symp. Cambridge University Press, London, p 265-276

Zajac RN, Whitlatch RB, Thrush SF (1998) Recolonisation and succession in soft-sediment infaunal communities: the spatial scale of controlling factors. Hydrobiology 376: $227-240$

Submitted: December 20,2000; Accepted: November 23, 2001 Proofs received from author(s): May 6, 2002 